NBER WORKING PAPER SERIES

\author{
WAGE DIFFERENTIALS IN ITALY: \\ MARKET FORCES, INSTITUTIONS, \\ AND INFLATION
}

Christopher L. Erikson

Andrea Ichino

Working Paper No. 4922

\author{
NATIONAL BUREAU OF ECONOMIC RESEARCH \\ 1050 Massachusetts Avenue \\ Cambridge, MA 02138 \\ November 1994
}

Originally prepared for the NBER conference: "Differences and Changes in Wage Structures" July 23-24, 1992, Cambridge, Massachusetts. Forthcoming in Freeman, R. and L. Katz, (eds.) "Differences and Changes in Wage Structures", University of Chicago Press. The authors thank Lawrence Katz and Richard Freeman for providing comments on earlier drafts, as well as seminar participants at the NBER conferences in September 1991 and July 1992, FIEF Stockholm and the Swedish Institute for Social Research. Pietro Ichino spent much time in long and insightful discussions with us. We also thank Ignazio Visco, Giuseppe Presutto, and Franco Santarelli for giving us access to the Bank of Italy, Assolombarda and Federmeccanica data sets, respectively. Luigi Cannari, Paolo Sestito and Luigi Guiso of the Bank of Italy were extremely patient in answering many questions on the Bank of Italy data set. Andrea Fioni was similarly helpful with the Assolombarda data set. Mark Jerger and Federica Zagari were very dedicated research assistants; the latter was occasionally helped by Patrizia Canziani, Roberto Benelli, Marco Bolandrina, Davide Lombardo, Marco Reverdito, Roberto Torresetti and in particular Francesca Nieddu and Carlo Tognato worked on inputting the Italian data sets. During the period this research was conducted, Erickson was supported in part by the UCLA Institute of Industrial Relations and Ichino was supported in part by IGIER and Fondazione Assicurazione Generali and benefited from the hospitality of FIEF. This paper is part of NBER's research program in Labor Studies. Any opinions expressed are those of the authors and not those of the National Bureau of Economic Research.

() 1994 by Christopher L. Erickson and Andrea Ichino. All rights reserved. Short sections of text, not to exceed two paragraphs, may be quoted without explicit permission provided that full credit, including () notice, is given to the source. 
NBER Working Paper $\$ 4922$

November 1994

\title{
WAGE DIFFERENTIALS IN ITALY: \\ MARKET FORCES, INSTITUTIONS, AND INFLATION
}

\begin{abstract}
During the 1970 s, Italy experienced an extreme compression of wage differentials, similar to the better-known situation in Sweden. Most evidence suggests that this compression came to a stop around 1982-83, coincident with a major institutional change (in the form of the escalator clause in Italian union contracts), a major economic change (the slowdown in inflation), a major technological change (industrial restructuring and the computer revolution), and a major political change (the loss of support for unions and their egalitarian pay policies). While we cannot definitively distinguish among the relative influences of institutions, market forces, technology and politics on the evolution of earnings inequality in Italy, our analysis of skill level wage differentials and our comparisons at the individual level with the more laissez-faire system of the United States suggest that both inflation and egalitarian wage-setting institutions have importantly influenced Italian wage compression in the regular sector of the economy. Yet, this very compression may well have contributed to the flight away from the regular sector of the economy at both ends of the skill distribution, plausibly leading to a greater overall degree of inequality for the whole economy than is apparent from our analysis of wage differentials in the regular sector.
\end{abstract}

Christopher L. Erickson

Anderson Graduate School of Management

University of California

405 Hilgard Avenue

Los Angeles, CA 90024
Andrea Ichino

Universita Bocconi

Via Sarfatti, 25

20136 Milano

ITALY 
During Ule 1970s. Jaly experienced an imp.essive compression of wage difierentials, sinilas to the beller-known sinzution in Sueder Most cridence suggests that dus compression cane 10 a stop around 1982.83, coincident with a major insritutional change (in the fom of the escalator clause in Italian union contacts), a major economic change (the slowdown in inhation), a major technelogical change (industrial testrucruning and the computer, tevolution), asd a major political change (the loss of support for unjoas and their egalitarian pay policies). There is some stight evidence of re-opening of difierentizls siace then, but the evidexce is unever, and even where 2 :c-opening is apparent, the degree of ineąjatity is still generally below the level of the early- 10 n:0. 19jCs.

In tis cliapier, we 272 jze the crolution of wage differentizls across still 2nd occupzional

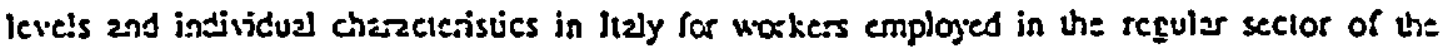
ceorani:- Workers who are not self eniplojed, have 2 bove ground jobs, and are not covered by special low'wage training contracts. The crifence ke piovife is consistent wiul vie view diat Lioss ueie able to pesh for instituiond refoms that compressed wage differenti2l's in the 1970 s. and that this cgaliarien irens hes been oaly perizlly, if at all, teversed in the 19SOs. IVhile w:

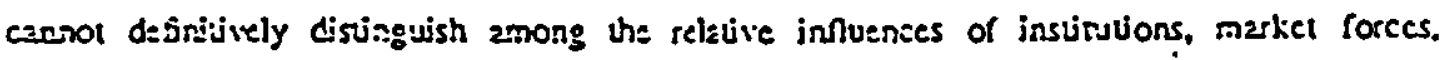

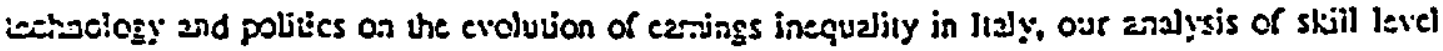
diffetenjals 2nd our congrasison at the individud level with the mo:e laisscz-\{aire sy.sicm of the Uaited S:aics suggest that both innzion and egzitariaz wzge-selving insuturons have imporanuly influexced Ii:lien kage oiticomss.

In the next section. We describe tre stiplized evidence on the recert crolution of "inge

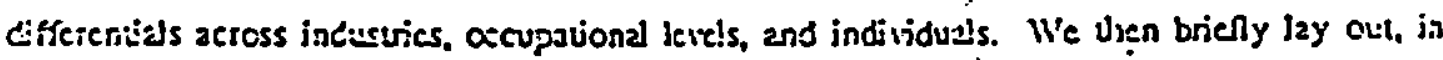
section II, the insulutional set.up of unge deleminavion in lialy. Wie also examine the ciolurion of

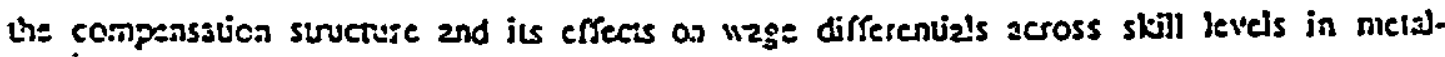
mavufacnisis, concentralisg in pericular an the effects of inflation. Our primairy indings here

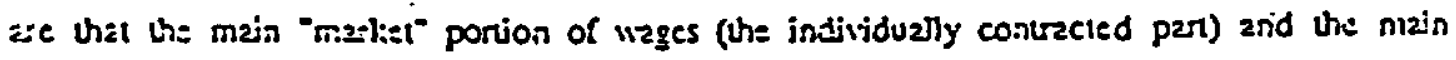
"instinijonal parica (the escalator pajments) lergely sene 10 cancel each other out, but that i.20:30. did have a sigrificant cfiect on kzge compiession befar igs3, less so recendy. In section III, we cxinise the deteminznts of ansual wage and salary income and ine desree of inegivily at the indisidtal level, compring raw inequabity and canings regressions fron a rep:esent3uve sample of lielien houscholds with the Uniled Siates Current Population Suricy: ue fond a maic conprissed compensz:jon structure in liely along almost all dimensions and a weat

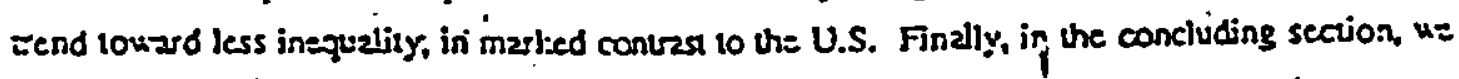
exzine the possible inipacts of this compression an self employment, the underground cconomy. 2id low-11zge trining coniras, thre mechanisms utich may tave increased overill inequality in lizly but are not capiuted in our quenvilavive andjsis of the regular sector of the economy: 
The main focus of this chapter is on carnings incquality across skill and occupational categorics witlun sectors and across individual characteristics. First, however, we examine some aggregate data on differentials across sectors. Figure 1 displays the coefficient of variation of blue collar hourly wages across industries from 1974 to 1985 (after which the serics was discontinued). The figure indicates a clear compression of differentials until 1982; afler 1982 the dispersion of bluc collar wages increased somewhah, but remained below its 1974 level in 1985. Again, this neasure of inequality is not our primary interest, but it goes back the furthest, and is consistent with the view that differentials lave not significantly widened recently.

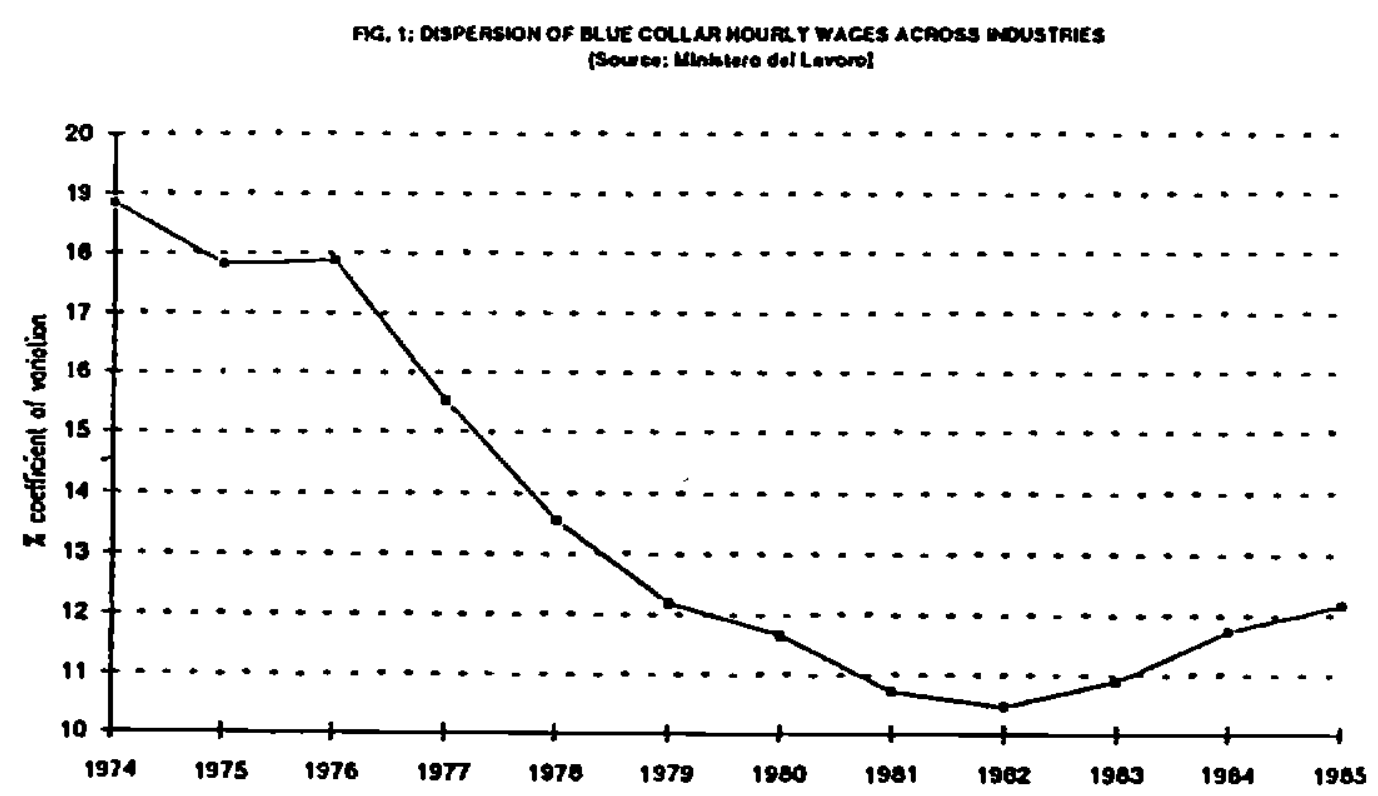

Figure 2 presents the ratio betwoen average white collar and average bluc collar montlyy wages within the inetal-manufacturing sector. Two series are presented leere: the Assolombarda scries, consisting of metal-nanufacturing firms in the Milan area, and the Federmeccanica serics. consisting of metal-manufacturing firms nation-wide. 1 Once again, we observe an unambiguous compression until 1983, followed by no clear trend in the Assolombarda series and some evidence

1 These data sets have been previously analyzed in ASAP 1986-1991 and Camiti Commission 1988. They are described in greater detail in the data appendix, along with the other dota sets usod in this chapler. 
of a widening of differentials in uhe Federmeccanica series, but not to the level of Uhe mid-1970s by Uhe beginning of Use $1990 \mathrm{~s}$.

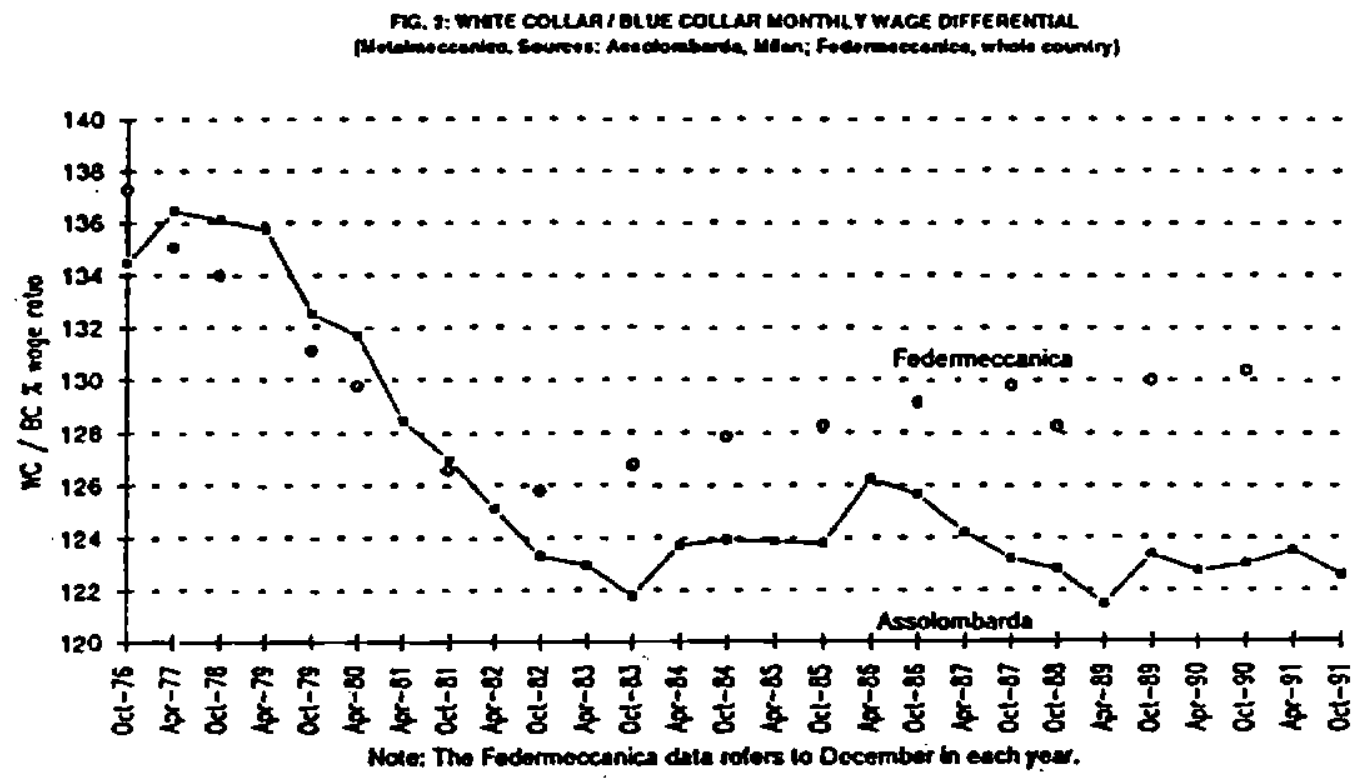

Finally, Table 1 displays the standard deviation of the logarithm of annual carnings from cmployment from a survey conducted for the Bank of taly over une period 1977-1987 (excluding 1981 and 1985). ${ }^{2}$ At this individual level, we find a continuing downward trend in inequality; in Section III, we analyze this downward trend and the determinants of individual labor income.

TABLE 1 DISPERSION OF INDIVIDUAL ANNUAL LABOR INCOME

\begin{tabular}{|c|c|c|c|c|c|c|c|c|c|}
\hline Year & 1977 & 1978 & 1979 & 1980 & 1982 & 1983 & 1984 & 1986 & 1987 \\
\hline $\begin{array}{c}\text { Standard Deviation } \\
\text { of logaritums }\end{array}$ & 0.46 & 0.44 & 0.44 & 0.41 & 0.42 & 0.41 & 0.39 & 0.38 & 0.37 \\
\hline
\end{tabular}

Source: Banca D'lialia

Overall, then, we do not see a clear trend toward significant widening of wage intequality in Uhesc findings, though the aggregate evidence does secm to indicate a leveling off of wage

2 The number given is tie standard deviation of the log of camings from comployment for full-tine, full-year. non-agricultural, non-self cmployed workers between the ages of 18 and 65 . This datn set is further explained and analyzed in section 111 and in the data appendix. 
compression around 1982-83. In the nexl section, we will see what the institutional set-up of wage determination can tell us about the trends we observe here.

Institutional Framework and Wage Differentials:

Descriptive Evidence from the Metal-Manufacturing Sector

\section{II.1 The Aciors ${ }^{3}$}

Three major unions (CGIL, CISL, UIL) have represented workers in Italy during the postwar period. These unions had their origins at the beginning of the cold war with the splitting of a unified union under government and U.S. pressures aimed at isolating Uhe lealian Conmunist Party (PCD. T1xe three unions were initially, and to some extent still are, characterized by different political inspirations, more or less related to the three main strains of ltalian politics: communist, christian denocratic, and social democratic, respectively. The political pressures to split the lialian labor novenent were, however, not enlirely successful, given that after a decade and for most of the remaining post war period the three unions have acted together. following a unified strategy, particularly in pursuing egalitarian compensation policies. It is only recenty, as we shall see below, that they love disagreed on some major substantive issues, and in particular on the reform of the indexation system.

It should be noted that CGIL, CISL and UIL are confederations of sectoral unions. The extent to which bargaining stralegies are coordinated across sectors is not, however, innuediately clear. Yet, sounc sectors secm to have played a leading role in the bargaining process; this is particularly true for ule netal-manufacturing sector, on which we will focus our analysis in this section. Contracts in metal nanufacturing cover a vast array of industries, including all metal transformation actlvities: industrial, electrical, and transportation tnachinery, computers, odher precision instruments and several smaller metal and machinery industries." Unions have traditionally had their strongholds in uhese industries, and, therefore, metal-manufacturing contracts lave ofien been the first to introduce signifieant pro-worker rules later extended to other sectoral bargaining unils. On a few oceasions, metal-manufacturing contracts have even been translated into law.

3 Sec Neufeld 1960, Giugni 1984, and Locke 1992 for more extensive English langunge analysis of Jatian industrial relations history and structure.

4 Metal-manufacturing workers accounted for approximately $1 / 3$ of all pon-self employod industrial workers and 1/10 of all non-self employed workers in 1990; we say "npproximately" because it is not possible to know exactly bow many workers are covered by the terms of the metal-inanufacturing contract. Metal-manufacturing production accounted for $38 \%$ or total industrial production. Source: Conßindustrin. 
Al private industrial employers are represented by a single association (Confindustria) that has traditionaly played the leading role in bargaining. Other sintilar associations represent cmployers in the other main sectors (trade, other services, arisans, agriculture), and an important role is also played by the association of companics that are partially owned by une governnuent (Parlecipasioni Statali) but operatc under market rules. Finally, the role of the public adnunistration as an cmployer has become increasingly intportant, particularly in recent years during wluch, in contrast to the past, industrial relations oulcones in uxe public sector have started to influence the private sector. 5

The relative strength of workers' unions and cmployers' associations, and the cxicnt to which Uxy lave been able to achieve their bargaining goals, have gone durough quitc substantial swings in the postwar period; we identify three major phases here. The 1950s and 1960s were a period of relative weakness of unions, although some initial steps were undertaken toward die construction of the strongly pro-worker legislation that now characterizes Italian industrial relations. 6 The Autumno Caldo (Hot Autumn) of 1969 was tue first important tuming point: a period of widespread social unrest and acute class conflict which gave unions cnornious popular support and bargaining power. The result was a tremendous pro-worker shift in legislation and bargaining outcomes: the most important example is the Statteto dei Lavoratori (Clianter of Workers Rights) that provided uxe workd-famous Italian workers' protection against firing as well as other significant labur narket regulations tial licavily constrainted the froedonts of eniployers in the labor market.

During une 1970s, the achievement of an egalitarian distribution of inconte was one of dxe focal objectives of unions, and given their relative strength during this period, they were able to induce a strong compression of wage differentials. Several collective contracts in tux carly 1970 s granted equal contractual increases to all workers, and in 1975 a new indexation system, to which we will return below, provided for cqual increases to all workers for each percentage point of inflation. The slogan "equal pay for all work" would have been subscribed to by most union Icaders during this period, and it is difficult to doubt that a large part of the compression of wage differentials observed in the 1970s (sec section I) was caused by the unions successful pursuit of cgalitarian pay policics.

The march aguinst unions by 40,000 high-level whitc collar workers in Turin (Ulc location of FLAT) in the fall of 1980 may be considered the second tuming point. The compression of wage differentials had reached a thresloold of unacoeplability for high-skilled workers, and uxir

5 Parcicularly innortant was the wave of contract renewals in public administration in the lite 1980s that granted large wage increases to public sector workers and apparently caused a ratcliet cffced on privale sector workers.

6 For cxample: laws on layolfs and firing, on the protoction of female workers, and on the prohibition of gender and regional based contractual pay differences. 
opposition to cgalitarianism, probably latent in the previous years, cante explicitly to the surface. In the neantine, the process of heavy plant restructuring, spurned by the oil shocks and hegun in the lase 1970), hisd exiended to a large part of the Hudustrial sector, resulting in major layofrs in the industrialized regions. The unions progressively began to lose menbers and public support, due in no small measure to their inability to protect less-skilled workers from layofrs and the opposition of the high-skilled woikers to egalitarianism.

Table 2 presents some illustrative figures on this recent diminution of union strengut. The first Iwo columns report measures of strike activity for the national industrial sector and for the Lombardy metal-manufacturing sector, respectively: both series display a significant decrease in the number of hours lost to labor conflicts after 1983. ${ }^{7}$ The last column reponts union membership for the metal-manufacturing sector in the Milan area. Different definitions of the "Milan area" in the publications from which these numbers were taken cast doubt on the exact comparability of uxese numbers across years. We are, neverulieless, confident about the basic message that can be taken from this colunun: union menbership has been steadily falling since une mid-1970s, with a significant drop at the beginning of the 1980s.

The result of dxese trends was a loss of bargaining power from which the dyree traditional major mions do not seen to hive recovered. Furdhermore, new corporative unions representing small groups of workers in crucial pusitions have actuired substantial power, particularly in public sector services, exacerbating the current weakness of une traditional Italiun labor novement All of this adds up to a labor novement with a dininishad ability (and perhaps willingness) to push Urouglı dicir cgalilarian pay policies.

\section{II.2 The bargaining structure and ule inquadramento ${ }^{8}$}

On the basis of an extensive interpretation of the Constitution, and in the absence of rules concening unions' certificalion, collective contracts signed by the three main unions have erga omnes validity as far as compensation is concerned (i.c. Utey apply to alt workers regardless of union status). Therefore, in ltaly union menbership may differ dramatically fron union coverage: the latter is always virtually $100 \%$ within each unit for which a collective contract is signed. Furdicmiore, collective contracts lave on a few oceasions been translated into law. Hence, the

$7 \quad$ An additional interesting fact conceming the significant reduction of strike activity in 1978 is that that was the year of the kidnapping of the Christian Democrat leader Aldo Moro by the Red Brigades. A governenent of national solidarity against terrorism and the economie crisis, with the extermal support of the PCI. was put in power on that oceasion. The general foeling of national solidarity against the Red 8 Brigades, sharad by ule PCI, contributed to the decrease in strike activity.

8 The literature on the lalian bargaining structure and on the inguadramento is large; we draw in particular on Carinci 1987 and P. Ichino 1992. 
influence of unions has reaclied those parts of the ceonomy that the unions liuve not directly organized.

TABLE 2 LABOR CONFLICTS AND UNION MEMBERSHIP, 1974-1990

\begin{tabular}{|c|c|c|c|}
\hline Year & $\begin{array}{l}\text { Averoge number of lours } \\
\text { lost to strikes per month, } \\
\text { (cntire industrial sector) }\end{array}$ & $\begin{array}{l}\text { Total number of hours lost } \\
\text { to strikes per year } \\
\text { (metal-manufacturing. } \\
\text { Lombardy) }{ }^{2}\end{array}$ & $\begin{array}{l}\text { CGIL, CISL \& UIL } \\
\text { members } \\
\text { (metal-manufacturillg. } \\
\text { Milan Arca) } \\
\end{array}$ \\
\hline 1974 & 6516 & & 196022 \\
\hline 1975 & 8424 & 19930 & 200288 \\
\hline 1976 & 10653 & 29553 & 193738 \\
\hline 1977 & 4138 & 17598 & 191108 \\
\hline 1978 & 2604 & 7773 & 184721 \\
\hline 1979 & 9685 & 28947 & 183486 \\
\hline 1980 & 11859 & 18549 & 179434 \\
\hline 1981 & 4067 & 10872 & 115340 \\
\hline 1982 & 4369 & 25267 & 102524 \\
\hline 1983 & 6216 & 19035 & 91568 \\
\hline 1984 & 800 & 5676 & 78574 \\
\hline 1985 & 1276 & 4531 & 72717 \\
\hline 1986 & 1182 & 2894 & 67854 \\
\hline 1987 & $\cos 2$ & 2705 & $42 \times 19$ \\
\hline IXSS & 1161 & 1190 & 40366 \\
\hline 1989 & 622 & 2271 & \\
\hline 1990 & 1953 & & \\
\hline
\end{tabular}

NOTES

1) Averige of the January, April, July and October number of hours lost to strikes in millions, from the Bank of Italy.

2) Totil number of bours lost in cach year in thousands, from Annuario di Statisticlie del Lavoro, ISTAT (Official Italian statistical office).

3) Number of members of the FLM (Federation of metal-manufacturing workers); this is the confederation that joinuly organizes CGIL, CISL and UIL workers in metal-snanufacturing.

Source: These data were collected at the FLM bistorical archive in Milan. 
Bargaining takes place at the national, sectoral, provincial and firm Ievels. Esscntially all aspects of labor relations may be a subject of negotialions, as long as the bargaining outconc is at least as favorable for the workers as what is implicd by the law. Bargaining at the national or provincial level can be characterized as a state-contingent process in the sense that it usually occurs when specific issues of gencral relevance need to be discussed; as far as compensation differentials are concemed, the most important issue discussed at the national level has been the indexation systein. In contrast, sectoral and firm level bargaining are better claracterized as timecontingent processes. Typically, sectoral contracts last approximately three years and, after the signing of each sectoral contract, bargaining at the firm level begins. The sectoral contract provides a wage floor for the firm level, but bargaining does not necessarily occur at the firm level. Indeed, during the early 1980 s Confindustria often advised its members not to bargain on wages at the firm level; norcover, unions at that time did not have enough strengul, in many firms, to push the discussion of wage increases beyond those granted by lhe sectoral contract.

Many of the outcones of collective agrecments are differentiated acruss workers according to a skill ranking systcm. The law first divides non-sclf cmployed workers into four catcgories: blue collar workers, while collar workers, quadi and managers. The nature of the occupation, whether manual or intellectual, traces the border line between blue collar workers and the other catcgories. while une anount of directive responsibilities traces the distinctions among the higher categorics. High level white collar workers with directive responsibilities, known as the quadri, were first recognized by lix law as a separate calegory in 1985. However, after the march of the 40,000 in 1980, collective contracts and employers acting independently from the contracts had already started to grant them some preferential treatment. The process that led to the recognition of the quadri as a separate category was one of the many signs that the compression of differentials achicved in the 1970s had gone 100 far for the unions' constituencies and the public at large.

Within uxe ranks of the non-managerial workers, collective contracts at the sectoral level furtier subdivide workers into several quasi-skill categories called ingtundramento levels. Wages and working conditions are attached to these levels and contracts establish which types of workers are in which level; instead of job descriptions, there are inquadranento descriptions.

In IJe 1950s and 1960s there were different inquadraniento levels for blue collar and white collar workers, while tie quadri category did not yet exist. The distinction between blue collar workers and white collar workers was, however, in evident contrast 10 uxe cgalitarian goals of the unions. Thxereforc, during their period of strength in the early 1970s, the unions tried to push, through collective bargaining, for the Inguadramento Unico: a single ranking structure for blue collar and white cellar wexkers. The geal was (o) make explicit the cyuivalence of tre skill content of manual ind intellectual work. The allemipt was, lowever, only partially successful, with blue 
and white collar workers ranked logether only in the bottom laalf of the inquadramento vilile only white collar workers were ranked in the upper half.

In the netal-manufacturing sector, for exauplc, there are ciglu inquadranento levels. 9 All blue collar workers are ranked in the first five levels; some bluc collar workers with directive responsibilities are called "inlemicdiates" and are ranked in the fourth and fifli levels. While collar workers are ranked in all levels but the first. Finally, the qualdri are ranked in lle scventh level. Thus, despite the cgilitarian gains of the unions, it is possible to identify is different skill ranks of workers in metal-manufacturing: 5 bluc collar levels, 2 intermediate levels, 7 whitc collars levels and 1 level for the quadri.

Our analysis in this section is based on the average monthly wages for these catcgories of workers for samples of firms from two data sets. The Assolombarda dala set is collected by the Lombardy section of Confindustria froin questionnaires sent to metal-manufacturing firms in the Milan Area. This data set provides fairly disaggregated information on the conponents of the compensation package. The Federnicceanica data set is collected by the nictal-manufacturing section of Confindustria and is based on firms in the whole country, but provides more limited information on components of the compensation package. 10

First, we believe it is important to get a sense of the extent of homogencity of these is calegories across firms, in tems of nonthly compensation. From une Assolombarda data set ste have access to the average monthly wages paid by cach firm to the workers in each of the is catcgorics for the years 1983-1990. The inquadramento Jevel of the workers expluins approximately $80 \%$ - $90 \%$ of the total variance of average monthly wages across inquadramicnio levels and firnıs. Furticrmorc, the (cuploynent weighted) within-inguadramento coeflicient of variation of the average monthly wages paid across the firms in the sample is never ahove $10 \%$ (i.c. the standard deviation is never larger than 10\% of the mean).

Lotking separately at bluc collar workers and white collitr workers, there is the most homogeneity within the central ranks of each of the two groups. It should be kept in mind. however, that very few firms in the Assolombarda data set rank workers in the lowest bluc collar and white collar levels, so the cocflicients of variation are not very significant for thesc two levels. In the rest of our analysis based on the Assolombarda data set we will drop these two levels. lintrainquadramento pay for white collar workers seems to be on average less bonogenoxus than for bluc collar workers, and for high white collar levels the coeflicient of variation is significantly larger. There is, then, apparently less pay homogeneity across firmis at high inquadramento levels.

9 The kevels are numbered from 1 to 7, but an additional catcgory called 5-super has boen added between tie fiflh and the sixth levels.

10 Furdher descriptions of these two date sets are provided in the dita appendix. 
Since we do not have access to individual wages in these data sets, we have litte to say about within-firmll variability. Limiting ourselves to differences across firnts, we take the above as cvidence that incquadramento levels expiain a large part of the variability of monthly compensation. In other words, workers in a given level seem to receive fairly sinilar wages in different firnis, although this is less true the higher the skill level. If one is willing to belicve that wage homogeneity reflects skill homogencity, and in the absence of betier neasures, inquadramento levels can then be considered as fairly satisfactory proxies for skill ranks.

The distribution of workers across inquadramento levels has undergone interesting changes in recent years. The Federmeccanica data set contains information on the proportion of workers in cach level which is comparable across years. Between 1976 and 1991 the proportion of bluc collutr workers in the non-managerial metal-manufacturing labor force decreased from $75.8 \%$ to $63.5 \%$. This decrease seems to have becn nainly duc to a decrease in the proportion of workers in the three lowest inquadrantento levels; since relalively few workers are ranked in the first two levels, most of the decrease in the bluc collar fraction of the labor force comes from the third level. As for white collar workers, the increase in their proportion of the labor force is almost entirely due to an increase in the proportion of workers ranked in the two highest levels. These trends are particularly evident between 1976 and 1987.

This evidence suggests that the metal-manufacturing sector undenwent a significant change in the conposition of its labor force across inquadramento levels between 1976 and 1987. There are two principal interpretations of this change in composition. First, inasnucl as ure inquadramento levels reflect skill levels, there may have been a shift away from lower stills and toward higler skills Unfortunitely, with our data, we have no way to measure how nuch of this shift was due to labor demand forces and how much to labor supply forces.

Second, these trends may simply be the result of intemal promotions during a period in which enployment growh in the metal-manufacturing sector was ninimal. In centralized bargaining systems, ungrading is a typical response to market forces pushing for more wage dispersion, resulting ultimately in an inplicit form of wage drif. Again, however, we cannot disentangle with our data the extent to which these trends in the composition of the labor force reflect technological shifts toward nore skill-intensive production and the extent to which they represent a form of wage drift. While reading the succeeding sections, though, keep in nind that on top of une wage drift that we will explicitly measure (as the non-collectively contracted portion of the compensation package), wage drift is also likely to have taken place implicilly through promotions. 


\section{II.3 The cempensalion structure and comnensalion differentials 11}

The structure of the typical compensation package for an Italian industrial worker is detailed in Table 3. The contractual mininum is detemuned at the sectoral bargaining level; the indexation systcm (scala mobile = cscalator), regulated by sectoral bargaining or by law, is thought of as protection for the purchasing power of ule contractual ninimum. Niese two components make up the contractual compensation. Bargaining at the firm level adds to this floor a wage increase called the collective superminimum and a component called the production premiun;; the latter component originally had an incentive function that was abandoned in the 1970s under union pressure, though it still remains in the compensation packagc. More recently, annual boauses, sometines in the form of profit sharing, and plant level incettive components luve also been introduced into firm level bargaining; scniority increases, in contrast, have always been determined at the sectoral level. The individual supermininiun is the last conponent of tie socalled base monthly compensation: it is detemined by the cniployer outside of any direct influenoe by unions - as we will sec, because of this feature, it has played a significant role in the determination of wage differentials.

Adding some minor extraordinary payments ${ }^{12}$ and overinic payments, ${ }^{13}$ we get to the total monthly conpensation. The annual compensation is not just equal to twelve nonthly installments, however, becausc in addition to the annual bonuses mentioned above, at least one by law), or two or in sone cases up to four additional "months" are added necording to the sectoral contracts. Finally, scveranoc payments are granted by law in any case of job separation.

Not all of these components are equally insportant, particularly as far as wage differenials are concerned. As shown in Table 4, the contractual minimum, the cumulated scata mobile payments ${ }^{14}$ and the individual superminimum accounted for betwoen $80 \%$ and $90 \%$ of the total monthly wage in 1991 in each inquadramento level, though their relative weiglts varied, as will be discussed below. Furliennore, because overime payments, severance payments and 13th month (and above) instaltments depend on the base monthly compensation, the beluvior of these trece components cssentially shape ule behavior of the entire compensation package. In ule remainder of this subsection, we describe the crolution and the detcrminants of these three key components.

11 The data sets on which this section is based have been used by several previous researchers. This section owes a lot to that literature, particularly ASAP 1986-1991, Caniti Commission 1988. Biagioli 1985, Biagioli 1988. Frey 1988, Bordogna 1988, and Lucifora and Presutw 1990.

12 Payusents for missions or compensating payments for specific job clarncteristies, for exnauple.

13 Overume payments are not included in the montly compensation data we use in the rest of this section.

14 Here and elsewhere in the figures and tables, we refer to scala mobile maments cumulaled since 1981. 
TABLE 3 THE STRUCTURE OF THE TYPICAL COMPENSATION PACKAGE*

1

Contractual mininuum (scctor)

$+$

Scala Moblle component (scctor, nation, or law)

$=$ Contractual compensation

+ Collective superminimum (firm)

+ Individual superminimum (individual)

+ Seniority increase (sector)

+ Production predium (sector / firm)

$=$ Bise monthly compensation

+ extrnordinary pay (sector, law)

+ overime payments (sector, law)

$=$ Monthly compensation

- 12

$+13 \mathrm{u}_{1} \cdot 14 \mathrm{th}_{1}$ inond/s, cle. (sector/ law)

+ Odier annual bonuses (scctor / firm)

= TOTAL ANNUAL COMPENSATION

+ Severance pay (law)

$=$ TOTAL, COMPENSATION

- The bargaining level at which the component is discussed, or whether it is deternined by law, is in parenulicses. 
TABLE 4 MAIN COMPONENTS OF THE MONTHLY WAGE AS A PERCENTAGE OF THE TOTAL, MILAN AREA METAL-MANUFACTURJNG SECTOR, 1991

\begin{tabular}{cccccc}
\hline Inquadranento Icvel & $\begin{array}{c}\text { Contractual } \\
\text { minimum }\end{array}$ & Seala Mobile & $\begin{array}{c}\text { Individual } \\
\text { supermin. }\end{array}$ & $\begin{array}{c}\text { Collective } \\
\text { supemin. }\end{array}$ & Other \\
\hline BC2 & 31.47 & 58.38 & 0.51 & 2.67 & 6.96 \\
BC3 & 31.62 & 53.12 & 1.30 & 2.95 & 11.01 \\
BC4 & 31.76 & 49.91 & 3.27 & 4.01 & 11.05 \\
BC5 & 32.35 & 45.62 & 3.54 & 3.96 & 14.53 \\
IN4 & 31.19 & 49.06 & 6.75 & 2.60 & 10.40 \\
IN5 & 30.35 & 42.80 & 12.10 & 4.54 & 10.20 \\
WC3 & 31.54 & 53.00 & 3.04 & 4.44 & 7.97 \\
WC4 & 31.22 & 49.08 & 4.83 & 5.86 & 9.01 \\
WC5 & 31.53 & 44.47 & 9.92 & 5.18 & 8.90 \\
WC55 & 30.28 & 39.56 & 14.37 & 4.15 & 11.63 \\
WC6 & 30.18 & 35.57 & 21.48 & 5.16 & 7.62 \\
WC7 & 29.47 & 27.91 & 30.06 & 4.22 & 8.34 \\
QU7 & 26.15 & 23.11 & 38.59 & 4.16 & 7.98 \\
\hline
\end{tabular}

Source: Assolombirda 
The courructual minimum

As previously mentioned, the floor of the entire wage struclure is the contraclual minimum. cslablished al the sectoral bargaining level. For cach inquadramento level and for eacli year of the contract, a mininum wage is agreed upon. As shown in Table 4 this component amounted to approximatcly $30 \%$ or total monthly wage in each inquadramento level in 1991.

With the exception of a few contracts in the carly 1970s, contracted minimum increases lave always displayed sone differentiation across inquadramento levels. Nevertheless, the compression of differentials for contracted levels continued until the end of the 1970s. For metalInanufacluring in the Milan urea, these trends are shown in Figure 3.15 In 1976 the contracted mininum for white collar workers in the seventh level was $80 \%$ more than for blue cullar workers in like second level. 'this percentage fell to $60 \%$ in 1979 and then grew more or less sicadily up to [W9!: in this ye:r the lighlict contracted minimum was almost twice the lowest.

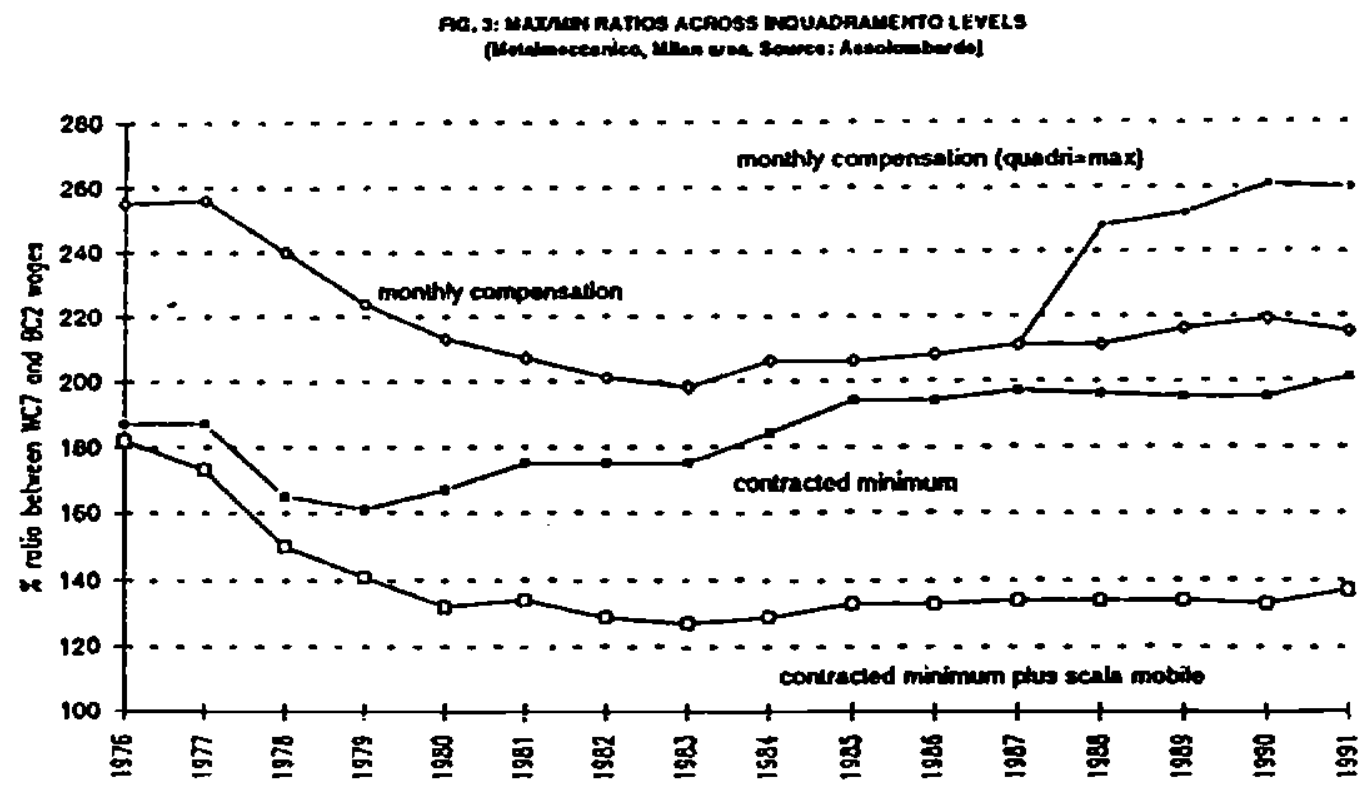

Figure 3 also shows the sane dispersion measure for lotal mondly compensation 16 This fifferential is larger than the contracted one in every year and has a $U$-stape, with a minimum in

15 Each point in this figure represents a compensation matio between the seventh while collar level and the secoud blue collar level, with the exception of the upper observations on montbly compensation post-1987 (see next foutnote).

16 Afier 1987 the figure reports two max/min rations for total compensation. The upper one uses the average wage of the quadri as the max. This should not necessarily be interpreled as a widening of dillerentials with respect to previous years, since the calcgory of the quadri was crealed by splitting the seventh white collar catcgory. As discussed above, the quadri staned being trealed differently long before 
1983: Uhis minimum occurs four years after the minimum of the contracled differential. In other words, despitc the fact that contracted differentials began to widen if the late-1970s, total differentials continued to compress. If ule contracted minimum plus scala mobile component is considered (the third scries displayed in Figure 3), the max/min ratio for this series also kecps decreasing until 1983. This cvidence suggests that inflation, in conjunction with the indexation system, bore major responsibility for Uhe compression of monthly wage differentials between 1979 and 1983.

The scala mubile ${ }^{17}$

Irklexation has a long and conflictual history in thaly, full of consepacnces for the crolution of wage differentials. The first escalator (scala mobile) was introdeced in bargaining at like mational level intmediatcly afler the warr. For each unit increase in the price index, equal wage increases (called munti di contingenza = points) were paid to workers in all sectors and inquadramento levels, but the increases were differentiated by region (ower in the south), gender (lower for women). and age (lower for young workers). A reference basket of goods was cstablished, which remains essentially unchanged today. The agreement, initially proposed by Confindustria, was explicilly interpreted by the parties as an exchange of indexation for social peacc.

The provision of equal scala payments for all workers (which ensured $100 \%$ coverage for the mean worker's contracied wage in 1946) clearly induced a compression of wage differentials. It also essentially provided zero coverage for subscquent contracted wage increases; yet, on the other hand, since the punti di contingenza were paid for each unit increase in Uxe price index (rather than for each nercentage point drop in the mean worker's real wagc, for example), this system accelerated unc reaction of wages to inflation. Such a system, therefore, requires periodic adjustments, first to provide coverage for subsequent contracted wage increases, and second to reduce the built in accelcration of the wage-price spiral.

The compression of differentials caused by this indexation sysicm, in conjunction will the high post wat inflation, soon lad to calls for the clinination of the cgatitivian aspects of the escalator. The systcm was slightly changed in 1951: the new systcil was still based on points, but lixe cscalatur increases were differentiated to provide $100 \%$ coverage for each inguadramento level and to maintain inter-inquadramento differentials on a $1(0)-239$ seale from the lowese bluc collar

this split The figure indicates, though, that due differential ureatunent of ute quadri, tidden in the seventh level before 1987, was indeed significant

17 For additional information on the debarc concerning tie seala mobilc and on its listory, sec D'Apice 1975. Quarchioni 1979, C.N.EL. 1981, Alleva 1986, Faustini 1987, and Mariani 1991. 
level to the highest white collar level. All other aspects remained unclanged, including zero covernge for future wage increases and the built-in accelemtor.

The scala mobile maintained this same basic structure until the nud-1970s, with periodic readjustments to provide coverage for interim contracted wage increases and to reduce the resction speed of the escalator. One major change, concerning not only the indexation system but also contracted wages, was the climination by law of scala mobile paynients and contracted wage differentiation by gender, age and region. The escalator, originally introduced in bargaining, was extended by law to the entire industrial sector in 1960. With few exceptions (the financial sector, for examiple) it was exicnded through contracts to the rest of the cconomy, although its nontrivial drawbacks in tern of coverage and wage-price spiral were already evident.

Then, when union strength increased dramatically after the Autunno Caldo, Uxe unions sought changes in the system. Most obviously, the egalitarian aspimtions of the carly 1970s claslied with the differentiation of scala mobile payments across inquadramento levels; in addition, given the large contracted wage increases of the early 1970s, and despite the periodic readjustnicnts. the coverage provided by the system had decreased. Finally, the first appearance of oil slrock inflation suggested to the unions the need for better protection of real wages.

Upon the unions request to Confindustria, a return to a fully cgalitarian escalator was negotiated in 1975: the parties agreed on a two year transition to a syslem where all workers would receive, at a guanerly frequency, equal escalator increases for each point increase of the price index in the previous quarter (i.c., similar to the 1945-46 system, but without differentiation by region, gender and age). 18 The scala point was set equal to the highest point of the previous system (upward equalization). In addition, a quite substantial fixed sum was paid to all workers as compensation for the lack of full coverage of interim wage increases under the old system. A 1977 law prolnibited escalator systems more favorable to workers than the escalator negotiated in 1975; Ulis implied de facto legal extension of the industrial sector esealator to the entire cconony.

Soinewliat surprisingly, Ule two najox drawbacks of the previous system (zero coverage of subscquent contracted increases and acceleration of uhe wage-price spiral) remained in place, while the potential for dramatic compressionary effects on wage differentials in a country already facing inflation in double digits was built in. In addition, the average coverage was dranatically raised by the upward equalization of the punti, iscreasing real rigidities potentially incompatible with the consequences of the oil shocks.

Indeed, between 1975 and 1983, while inflation fluctualed between 10\% and 20\% (Figure 4), Une potential for wage conpression became a reality, as shown by the evidence presented in the

18 Note Use similarity of this system to the escalator clauses in many US. union contracts: in the avtomobile and acrospace industries, for example, COLA clauses oflen specify across-the-board cents-perhour wage increnses for given increases in the consumer price index. 
first section and in Figure 3: the dispersion of all the measures we consider (except the contracted minimum alone) and in particular the contracted plus scala mobile component of the compensation package display a continuing compression until 1982-83. Despitc the increasing high-skilled workers' opposition to uage compression, unions remained attached to the egalitarian nature of the scala mobilc. They also opposed any attempts to cut ule degree of coverage and the reaction specd of the escalator.

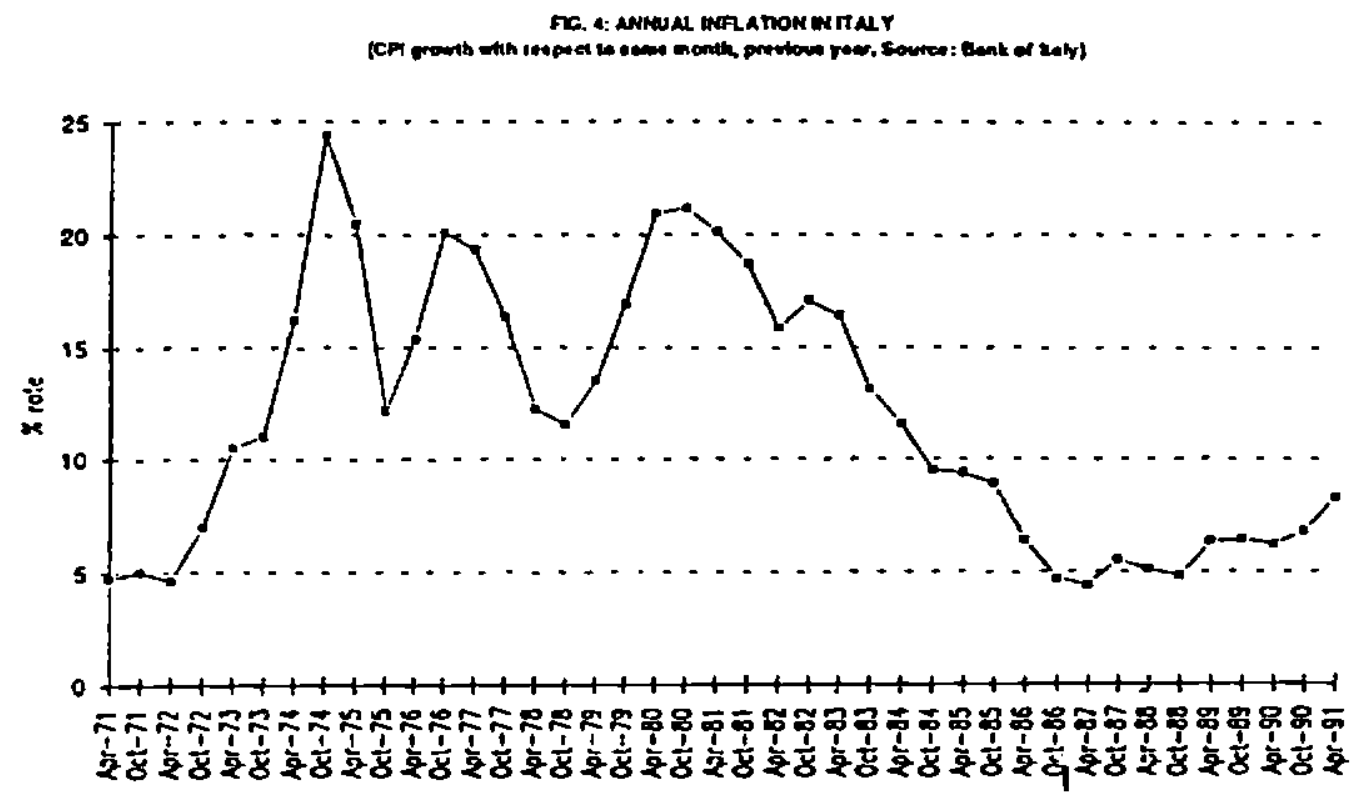

On these latter issues, lrowever, the three unions came to fundamental disagneement after many years of unificd action. In 1983, CISL and UIL joined in an agreenent with enployers (spcarleaded by ue govenument) which implenented a $15 \%$ downward adjustment in ule degree of coverage, followed in 1984 by a predetermined cap on scala payments. The communist majority witlun uxe CGIL opposed the agreements, and together with the PCI uley pustied for a referendun against the 1984 agreenent. The referendum, held in 1985, acquircd a political imporance that went far beyond the relevance of the money involved: it became a referendun on the scala mobile. The result was a defeal for the PCl aud the CGIL that signalled the crid of the otd indexation systeni.

On ule wave of ule referendum results. Confindustria was strong enough to fully reject as a whole the old indexation system. However, the bargaining process over a new system between Confindustria and the unions came to a dead end. The Government was therefore compelled to directly intervene in order to avoid social unrest, doing so in 1986 with a law on indexation that 
imposed a new fublic sector escalator on Uie cntire ceonomy. The point-based systeın was abautoned for someding analogous to a progressive tax systen: 100\% coverage for a portion of the contracted compensation (equivalent to ule contractual mininum of a medium lesel worker). with the remainder up to the total contractual compensation (contractual mininum plus scala Inobile: sec Table 3) indexed at 25\%. All oher compensation components were uncovered. The average overall degree of indexation was approximately $50 \%$ for bluc collar workers and $40 \%$ for white collar workers.

The law expired in 1990 and was extended for one year in the hopes that the parics would reach a solution. In December 1991 the parties decided to suspend the existing indexation system (begun in 1986) and to open, in June 1992, a new bargaining round aimed at a comprehensive reform of the entire compensation system, including indexation. The trade unions, the enployers and the government canc to a first agreement at the end of July 1992. Despitc the strong opposition of the communist left in the CGIL, the July agreement brought the death of ure scala mobile: in exchange for the elimination of the indexation systen, ltalian workers were to receive mondaly lump sum payments beginning in January 1993 equal, for everyone, to slightly nore than $1 \%$ of the niontlly wage of the lowest level blue collar worker in 1990. In addition, bargaining at the firm level was suspended by the July agreement until the end of 1993.19

This agrecment clearly has the favor of a large concession from workers to employers, and in fact generated much opposition among some union members. In addition, the subsequent exclange mite crisis of the Lira, initiated in September 1992 and followed by a stabilization program proposed by the government, made the July agreement even more difficult for the unions base constituency to accept: the devaluation generated a widespread fear of growing inflation in the absence of indexition, while the stabilization program (more taxes and fewer social expenditures) contradicted sonie of the commitments made in July by the government

Returning to the $1986 \mathrm{reform}$, it apparently did nol induce very much differentiation across inquadmunento levels: Figure 3 indicates that the nax/min ratio of the contracted minimum plus scala mohile component increased only slightly in the late 1980s, although the differential for the contracted increase shows a more marked upward trend. We see in Table 4 that in 1991 the portion of total conipensation accounted for by the scala mobile payments cumulated since 1981 still shrinks as we nove to higher inquadramento levels; during the 1980s, the indexation system did not fully protect the wages of high-skilled workers. Table 4 secms, however, to suggest that the third main component of the cumpensation package, the individual superntinimum, has at least partially compensaled the high-skilled workers for the low coverage provided by the scala mobile systen.

19 As for the comprehensive discussion of the entire compiensition structure, the agreement only mentions a generic commitment of the parties to discuss the issue in future bargaining rounds. 
The collecrive and the individual supcminina

Bargaining at the firm level has clearly influenced wage differentials. The main portion of the compensation package that is detcrmined at Ulis level is the collective supermininum (sce Table 3). The ratio between the highest and the lowest inquadramento levels for the cross-firm average of Uus wage component (from the Assolombarda data set) ranged from 233 in 1976 to 339 in 1991. while for the contracted nunimum the ratio ranged from 187 to 201 over the sane time period; however, Uxe collective superminimum ratio is still relatively small if we compare it to tue ratio for the individual supcrntinimum, which ranged from 3670 in 1976 to 12708 in 1991.

The individual superminimum is the part of the monthly wage that is delemined by the employer specifically for each korker and, therefore, is the only compinent of the compensation packige that is not regulated by collective bargaining or by tue law. As shown in Table 4, this component is practically insignificant at low inquadranento levels but grows to almost $40 \%$ of the compensation package at the highest white collar level. All together, ltis evidence suggests that the individual supernunimum is the main instrument by which individual employer-worker bargaining influences wage dispersion

Some interesting descriptive evidence on the role of this component is provided in Table 5. This table, based on Federmeccanica data, displays the following decomposition of Ule annual increase in monthly compersation:

$$
\log \left(\frac{W T_{1}}{W T_{t-1}}\right)=\log \left(\frac{W C S_{1}}{W r_{t-1}}\right)+\log \left(\frac{W T_{1}}{W C S_{l}}\right)
$$

where: $W T=$ total monthly compensation, $W C S=$ contracted minimum wage plus cumulated scala mobile. and $t$ indexes years. That is, the total percentage monthly wage increase between two ycars can be decomposed into the sum of the peroentage increase due to the scala mobile and the contract, plus the log of the ratio between the total wage and the contracted plus scala mobile portion. This last $\mathrm{term}$ is known in the literature as the drift rate. 20 Table 5 presents, for each inquadrumento level, the averages of these thee terms for the 1976-1982 and the 1983-1990 periods. This data set does not ofrer scparate information on the individual supcrmininum and therefore we can only exanine the overall drift. We know, however, from the above evidence that as far as differentials are concerned the individual superminimum is the most important component of the drift.

20 Sec, for cxample, Hibbs and Locking 1991. 
TABLE 5 DECOMPOSITION OF THE TOTAL MONTHLY WAGE INCREASE

IN THE NATION-WIDE METAL-MANUFACTURING SECTOR

\begin{tabular}{|c|ccc|ccc|}
\hline luquadratnento level & \multicolumn{3}{|c|}{$1976-1982$ avcrages } & \multicolumn{3}{c|}{$1983-1990$ averages } \\
\hline & $\begin{array}{c}\text { tothl wage } \\
\text { growth }\end{array}$ & drift & $\begin{array}{c}\text { coneract } \\
\text { plus scala }\end{array}$ & $\begin{array}{c}\text { lotal wage } \\
\text { growth }\end{array}$ & drift & $\begin{array}{c}\text { contract } \\
\text { plus scala }\end{array}$ \\
\hline BCl & 18.50 & 13.71 & 4.79 & 7.54 & 12.07 & -4.53 \\
BC2 & 17.61 & 16.33 & 1.28 & 7.43 & 14.31 & -6.83 \\
BC3 & 17.18 & 19.49 & -2.32 & 7.90 & 19.40 & -11.51 \\
BC4 & 16.90 & 20.77 & -3.87 & 7.96 & 21.52 & -13.56 \\
BC5 & 16.57 & 22.29 & -5.72 & 8.20 & 24.81 & -16.60 \\
IN4 & 16.51 & 28.32 & -11.81 & 8.01 & 27.69 & -19.68 \\
IN5 & 15.60 & 33.89 & -18.28 & 8.27 & 31.08 & -22.81 \\
WC2 & 17.87 & 13.79 & 4.08 & 6.93 & 10.12 & -3.18 \\
WC3 & 17.55 & 20.45 & -2.90 & 7.05 & 17.81 & -10.75 \\
WC4 & 17.04 & 25.20 & -8.16 & 7.07 & 21.92 & -14.85 \\
WC5 & 15.64 & 29.48 & -13.34 & 7.58 & 29.75 & -21.37 \\
WC55 & 15.06 & 33.35 & -18.28 & 7.98 & 34.01 & -26.04 \\
WC6. & 13.92 & 41.00 & -27.08 & 8.59 & 45.92 & -37.33 \\
WC7 & 14.91 & 62.11 & -47.20 & 10.08 & 73.36 & -63.29 \\
\hline
\end{tabular}

Source: Federmeceanica

Looking at total wage growth in the different inquadramento levels, the compression of wage differentials in the first sub-period and the expansion in the second appear evident. ${ }^{21}$ But what is uost striking in this thble is the existence of a scissor between the drift ratc and the increase due to the contract plus tue scala mobile, which grows larger as we move across inquadramento tevels. Notice also that in the second sub-period the size of the scissor clearly widens, particularly in the higher white collar levels. Conbining the evidence provided by this table and by Figure 3, it seems that the disequalizing effect of the drift rate became greater in the second sub-period, when infation was lower, but that this component has acted primarily to offset the equalizing $c$ flect of the escalator.

21 Keep in mind that while white collar (WC) inquadramento levels are listed after blue colthr (BC) levels in the table, BC and WC workers in the same level are comparable in tenns of the contracted portion of the compensation package. 


\section{II.4 Inflasion and wage dispecsion}

Given the above evidence, it can be argued that inflation affected wage differentials througl two interrelaled channcls, one direct and one indirect. The direct channel worked durouglt the cgalitarian indexation mechanism and generaled a compressionary effect on the wage distribution. The indirect channel worked instead through die drift: the higher inflation, the grealer is likely to have been the extent of Ulue use of the drift on the part of cniployers to oflset the compression caused by the scala mobile; this second channel generaled an expansionary effect on the wage distribution.

Since the percenlage increase in tolal wage dispersion is a function of clanges in the dispersion due to the escalator and to the drift, one can estimate the reduced form overall effect of inflation on the change in total wage dispersion and thus get a sense of which of these two channels prevailed. The results of this reduced form estimation are contained in the following equation, estimated over Ule 1976-1990 period on Federnieccanica data:

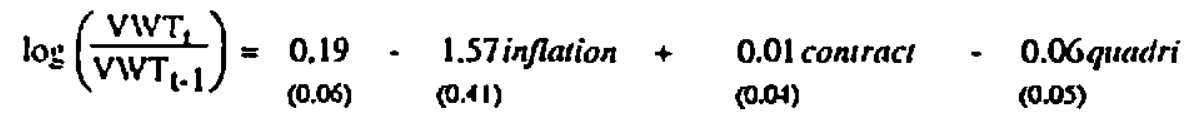

where VIVT is the variance of the log of monthly wages across inquadramento levels (excluding the quadri), comtroct is a dunnly variable that takes value one in the ycars in which a contract is signed and guadri is a dummy variable that takes the value $I$ for the years in which the quadri were separated froin uxe seventh white collar level. Inflation, through the scala nobile and the drift, clearly had a strong negative and significant effect on the percentage change in wage dispersion. Therefore, the disequalizing effect of the wage drift was not strong cnough to complecty offset the cortipression of dillerentials caused by the indexation systent.

On lixe oller land, when we distinguish helwoen die two sub-periuxls anatlyzed in Table 5. we oblain the following result:

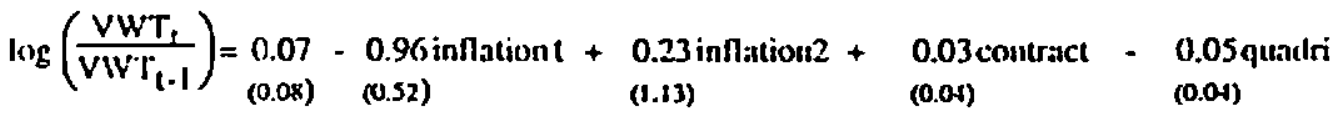

where inflation (inflation2) is cqual to inhation for the ycars 1976-1982 (1983-1990) and zero otherwise, and the other variables are definod as above. Here we see that inflation significantly compressed wages only until 1982. After 1982, inflation does not seem to have affected wage differentials, despile the persistently egalitarian nature of the escalator. This suggests that in the second sub-period the disequalizing effect of the drift became relatively stronger and capable of practically offsetling the effect of the escalator. 
What we lave found, then, is that a large part of the compression generated by 20 years of inflation and egalitarian institutions secms to still be present. We next sec what we can lean fron individual data and a comparison with the United States, where egalitarian wage-setung institutions clcarly play a inuclı less significant rolc.

111 Individual Characteristics and Eamings Inequality:

A Comparison of Italy and the United States

We now turn to an analysis of individunl-level data on the deterninants of annual uage and salary carnings in ltaly, using the United States as a benchmark. We first describe the trends in cducational attainment and the age struclures of our samples of workers in the two countries over the period under study, 1978-1987, finding roughly sinular age structures and a higher average level of educational attainment in the U.S., but a trend toward more educaled work forces in both countrics. We unen examine returns to schooling and experience and measures of overal camings inequality in the two countrics. Our nain findings here are that overall incquality and returns to skill (asy measured by the variability of actual and residual log carnings and the retum to a college degrec) are unambiguously higher in the U.S. than in Italy, and that while incquality has clcarly increased in the U.S., the pattern is less clear in Italy - indicating, if anything, a trend toward a less uncqual distribution.

\section{III.1 Dilla}

The Italian data source is a representative houschold survey collected by a private company for tue Banca D'lalia over the period 1978-1987, excluding 1981 and 1985; we shall refer to tlus dala set as BDI. 22 For the U.S., we use the March Currene Population Survey (CPS). Severill data limitations for BDI require discussion. First, the dependent variable is the log of annual carnings from employment net of taxes, which does not lave an exact cquivalent in the CPS; we use CPS annual gross wage and salary carnings. ${ }^{23}$ Schooling and age are nol conlinuous in BDI, but are segmented into five and six categories, respectively (schrooling calcgorics: no sclıouling, coniplesed elenentary, conipleted junior ligh, completed ligh school, and

22 This dati was previously analyzed in Cannari, Pellegrini and Sestio 1989 and Sestito 1990, who cstimated camings functions for Italy and examined the residual variance, concluding that there tas been no significant increase in incquality. We thank them for their insigbts and the Bank of Italy for providing the dith.

The survey was taken in 1981, but the dath in that year deviates from the aljacent years along cnough dimensions to be higlny suspect; we exclude it. No survey was taken in 1985.

23 We discuss the Italian tax system and its possible effects on eamings incqualiny below. 
college or higher degrec; age calegories: under 21, 21-30, 31-40, 41-50, 51-65, and over 65); for our comparauve regressions, we similarly segment the CPS dala, making the sclooling calcgories none $=$ completed grade 0-5; elenentary = compleled grade 6-8; junior ligh = completed grade 911; high school $=$ compleled grade 12-15; and colleget $=$ compleled grade 16+. Noic that BDI does not contain information on the worker's inquadramento level.

Finally, we restrict our samples to full-tinc full-year non-agriculturill workers belwoen die ages of 18 and 65 who are not self-enuployed Earnings are not lop-coded in BDI; we impulc lopeoded CPS annual carnings at 1.45 times the annual topeode amount (following Kalz and Mfurplyy 1992). IVe do all of our analysis separately for nuen and women. 24

\subsection{Aqu and Education Compositions of the Lahor Forces}

First, we cxanine the levels and changes of uxe age and occupational siructures in Uac iwo countrics. Table 6 presents the siniple proportions for the five schooling and five age calcyorics in the two countries for men and women in 1978 and 1987. Nole in particulas ule generally higlier level of schooling in tux U.S, and the rough similarity of the age distributions. Frnm the beginning of this period to the end of this period, the proportion of Italian men in this simple who had not completed high school fell $11 \%$ (from 66.7\% to 59.3\%), while the proportion of their American malc counterparts who had not completed ligh school fell $32 \%$ (from 21.9\% to 14.8\%); the proportion of Jtalian nen with college degrees rose 31\% and uxe proportion of Americin men with college degrees rose $24 \%$. For Italian wornen, une proportion who had not complesed high school fell 23\% and the proportion with college degrees rose 51\%; the corresponding numbers for American women in the CPS sample are $-43 \%$ and $36 \%$. In both countries, then, there was a trend toward grealer educational attainnent anong full- time workers over this periol. 25 We will return to these lindings and their possible roles in explaining the trends in oyerall incequality.

24 The inale/fenitle eamings differential is greater in the U.S. Uhan in Italy, ind is dropping faster in we U.S. W' refer Ule reader to Blau and Kalin 1993 for analysis of Ule gender eanings gap in ltaly and clscwilere.

25 IVe call use Ulese five age and five schooling levels to creatc 25 age-sclooling catcgorics, Ule finest division possible for the lealian sunple along the dimensions of schooling and expericnce. For Aunericans, both unen and women in both 1978 and 1987. Uhe largest age-education categories are always high school aged 21-30 and 31-40. The largest age-oducation categories in 1978 for lialian men wene junior light aged 21-30 and elementary aged 51-65; in 1987, junior high and biglt setwol aged 31-40. In 1978. the largest eategories for Ialian women were high sdroul and junior high aged 21-30; in 1987, hight school aged 21-30 and 31-40 (as in the U.S.). Apart from the generally higher level of scliouling in Uhe U.S., Uhe two countrics look reasonably sinilar in terms of the distribution of age colturts within schooling categories, and all of the distributions secm to be moving toward older iuld utore alucaned proputaiosts

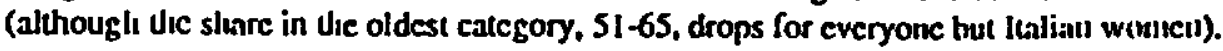




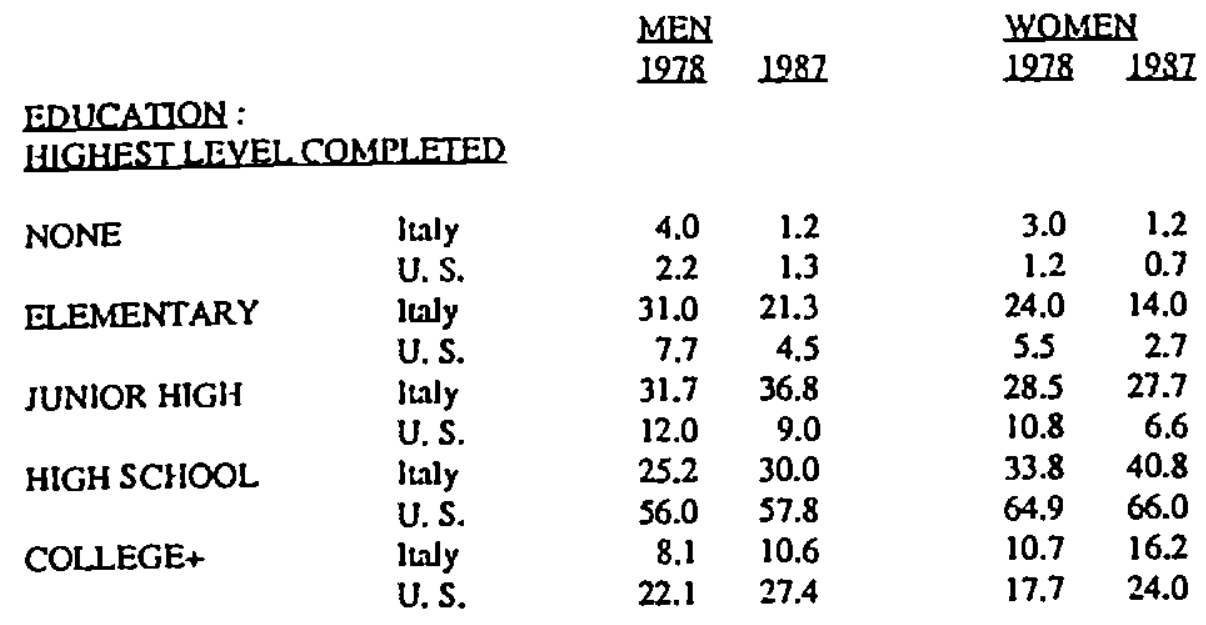

\section{AGECATEGORY}

$18-20$

$21-30$

$31-40$

$41-50$

$51-65$
Italy

U.S.

Jalily

U.S.

Ituily

U.S.

Italy

U.S.

Italy

U.S.
3.6

2.9

23.5

27.3

26.7

26.7

23.5

21.2

22.8

21.9
1.6

1.9

21.0

27.3

29.3

32.1

27.5

21.0

20.6

17.8
$7.1 \quad 2.6$

$4.2 \quad 2.2$

$34.9 \quad 27.7$

$31.7 \quad 30.4$

$27.5 \quad 33.4$

$22.1 \quad 30.4$

$21.0 \quad 25.1$

$20.4 \quad 20.7$

$9.5 \quad 11.2$

$21.7 \quad 16.2$

EXPERIENCE

Italy

$25.7 \quad 25.3$

U.S.

22.0

20.7

$19.9 \quad 20.9$

$21.2 \quad 19.8$

Noles:

1) Tor education and age calegories, the number given is the percentage of the particular gender's total sample of full-time full-year non-agricultural worters who are nol self-employed age 18-65 accounted for by particular calcgory.

2) Highest level conpleted in U.S.: None $=$ completed grade 0-5. Elententary $=6-8$. Junior High $=9-11$. High School $=12-15$, College $+=16+$.

3) Expcricnce $=$ mean of agc calcgory minus ycars-to-compiction of schooling calcgory tninus six.

Sources of data: Banca DTtalia, U.S. Current Population Survey. 


\section{III.3 Elucition Eamings Difrerentials}

We now exanuine differences and changes in the return to human capital characteristics. Looking first at the raw evidence on the influence of schooling on carnings, significant cross country differences appear to exist in education-earnings profiles. Table 7 presents raw (completed ligh school)/(did not complete high school). and (college degrec)/(completed ligh school) average carnings matios for nen and women in eacly country, for four age groups (combining the youngest (wo in Table 6, to create the 18-30 category). Both mitios rise in every age-gender group from the beginning of the period to the end of the period among Americans, and Uxe college/ls gap rises in all groups but one in ltaly (men 41 - 50). Yet, the hs/(less than hs) gap was smaller in 1987 than in 1978 in 6 of the 8 age-gender groups in tialy (except age 31-40 for both nen and women). By 1987. the ratios for Americans were greater than or equal to the corresponding mulos for llalians in every age-gender group.

Differences also secm to exist in the shape of the raw education-carnings profiles. In most cascs, the collegehis gap is greater than the las/(less than hs) gap in the U.S., but the opposite is often tue in ltaly, particularly among the older colorts and in the later years. This suggests that education-carnings profiles tend to be convex in the U.S. and concave in Italy.

We investigate these cducation-camings relationships further by comparing uxe coefficients from logarithmic earnings functions estinated scparately for men and women in the two countrics. Tables 8 and 9 present the coefficients on experience (defined as the nean of the age ealegory cecupicd by a given obscrvation minus the years-10-0ompletion of the schooling category nutnus six), experience sugured, and three schooling levels (up to conipleted elenientary, completed junior ligh, and college degree +; completed high school is the excluded category) for the years 1978 ulrough $19 \$ 7$ for men and women, respectively.

There are scveral interesting results from uxese regressions. First, judging hy the adjusted R-squares. the explanatory power for the regressions are roughly comparable across the two countries within gender groups. Sccond, while the returns to tigh school as well as colliege are clearly rising for both men and wonen in ule U.S., the trend is much less clear in ltaly - indicating, if anything. a weak trend toward lower returns to high school (relative to those with elenentary or less in p:urticular) and higher seturns to college. 26

26 Nore the large jump in relums to college for men in 1983. This jump connes prinarily from those cmployed in "public administration;" the retum for thuse employed in "industry" actually falls slightly. 
TABLE 7 EDUCATION EARNINGS RATIOS BY AGE GROUPS. ITALY AND U.S., 1978-1987 (Excluding 1981 \& 19SS)

MEN

$\begin{array}{llllllll}78 & 79 & 80 & 82 & 83 & 84 & 86 & 87\end{array}$

\begin{tabular}{|c|c|c|c|c|c|c|c|c|c|}
\hline \multirow[t]{4}{*}{$18-30$} & laly $[A]$ & 1.13 & 1.14 & 1.23 & 1.21 & 1.16 & 1.14 & 1.20 & 1.11 \\
\hline & ltaly [B] & 1.25 & 1.18 & 1.24 & 1.13 & 1.22 & 1.25 & 1.29 & 1.38 \\
\hline & U.S. $[A]$ & 1.27 & 1.27 & 1.24 & 1.22 & 1.31 & 1.32 & 1.31 & 1.35 \\
\hline & U. S. [B] & 1.26 & 1.24 & 1.23 & 1.29 & 1.33 & 1.35 & 1.43 & 1.48 \\
\hline \multirow[t]{4}{*}{$31-40$} & Italy $[A]$ & 1.18 & 1.27 & 1.22 & 1.23 & 1.16 & 1.18 & 1.15 & 1.19 \\
\hline & lanly [B] & 1.14 & 1.02 & 1.07 & 1.06 & 1.25 & 1.08 & 1.08 & 1.27 \\
\hline & U.S. $[\Lambda]$ & 1.31 & 1.34 & 1.35 & 1.41 & 1.37 & 1.35 & 1.41 & 1.40 \\
\hline & U.S. [B] & 1.29 & 1.27 & 1.24 & 1.26 & 1.31 & 1.34 & 1.41 & 1.41 \\
\hline \multirow[t]{4}{*}{$41-50$} & Italy $[A]$ & 1.36 & 1.51 & 1.31 & 1.30 & 1.29 & 1.30 & 1.29 & 1.23 \\
\hline & Ifaly [B] & 1.24 & 1.01 & 1.25 & 1.21 & 1.19 & 1.24 & 1.07 & 1.19 \\
\hline & U.S. [A] & 1.32 & 1.30 & 1.30 & 1.35 & 1.43 & 1.38 & 1.40 & 1.40 \\
\hline & U.S. [B] & 1.43 & 1.43 & 1.44 & 1.41 & 1.45 & 1.45 & 1.49 & 1.49 \\
\hline \multirow[t]{4}{*}{$51-65$} & Italy $[A]$ & 1.51 & 1.36 & 1.33 & 1.39 & 1.31 & 1.44 & 1.34 & 1.36 \\
\hline & Italy (B) & 1.28 & 1.45 & 1.33 & 1.12 & 1.33 & 1.29 & 1.32 & 1.31 \\
\hline & U.S. $[\Lambda]$ & 1.33 & 1.32 & 1.32 & 1.32 & 1.38 & 1.32 & 1.36 & 1.36 \\
\hline & U.S. $[B]$ & 1.56 & 1.51 & 1.51 & 1.50 & 1.56 & 1.56 & 1.59 & 1.58 \\
\hline
\end{tabular}

WWOMEN

\begin{tabular}{|c|c|c|c|c|c|c|c|c|c|}
\hline \multirow[t]{4}{*}{18.30} & Itouly [A] & 1.24 & 1.22 & 1.14 & 1.16 & 1.10 & 1.21 & 1.18 & 1.17 \\
\hline & Italy [B] & 1.06 & 1.02 & 1.23 & 1.14 & 1.28 & 1.13 & 1.28 & 1.30 \\
\hline & U.S. [A] & 1.24 & 1.24 & 1.22 & 1.33 & 1.31 & 1.33 & 1.38 & 1.30 \\
\hline & U.S. [B] & 1.31 & 1.33 & 1.35 & 1.38 & 1.37 & 1.38 & 1.45 & 1.51 \\
\hline \multirow[t]{4}{*}{$31-40$} & ltally [A] & 1.20 & 1.32 & 1.15 & 1.24 & 1.38 & 1.24 & 1.23 & 1.24 \\
\hline & Italy [B] & 1.01 & 1.05 & 1.01 & 1.06 & 1.04 & 1.08 & 1.04 & 1.03 \\
\hline & U.S. [A] & 1.35 & 1.23 & 1.29 & 1.35 & 1.43 & 1.39 & 1.40 & 1.46 \\
\hline & U.S. [B] & 1.44 & 1.46 & 1.43 & 1.37 & 1.40 & 1.41 & 1.42 & 1.48 \\
\hline \multirow[t]{4}{*}{$41 \cdot 50$} & Italy $|A|$ & 1.39 & 1.30 & 1.33 & 1.37 & 1.19 & 1.32 & 1.26 & 1.27 \\
\hline & Inly [B] & 1.08 & 1.05 & 0.98 & 1.06 & 1.10 & 1.09 & 1.08 & I.11 \\
\hline & U.S. $[A]$ & 1.33 & 1.27 & 1.29 & 1.34 & 1.36 & 1.33 & 1.41 & 1.46 \\
\hline & U.S. [B] & 1.44 & 1.47 & 1.43 & 1.39 & 1.46 & 1.44 & 1.47 & 1.50 \\
\hline \multirow[t]{4}{*}{$51-65$} & Itily $[A]$ & 1.46 & 1.61 & 1.38 & 1.38 & 1.43 & 1.37 & 1.38 & 1.40 \\
\hline & latly $[B]$ & 0.91 & 1.01 & 1.20 & 1.06 & 1.21 & 1.08 & 1.06 & 1.06 \\
\hline & U.S. $[A]$ & 1.34 & 1.36 & 1.34 & 1.39 & 1.42 & 1.32 & 1.34 & 1.41 \\
\hline & U.S. [B] & 1.42 & 1.43 & 1.50 & 1.37 & 1.40 & 1.52 & 1.50 & 1.46 \\
\hline
\end{tabular}

ltaly[A] and U.S. [A] = Cotnpleted High School / Did Not Complete High School average camings ratio. italy[B] and U.S.[B] = College Degroe or more / Completed High School average carnings ratio.

Note: Eanoings = annual wage and salary carnings, full-time full-ycar non-agricultural workers who ire not self-employed age 18-65. Pre-tax in U.S $\rightarrow$ post-tax in laly.

Sources of Data: Banca D'lialia, U.S. Curtent Population Survey. 


\begin{tabular}{|c|c|c|c|c|c|c|c|c|c|}
\hline & & 78 & 79 & 80 & 82 & 83 & 84 & 86 & 87 \\
\hline \multirow[t]{2}{*}{$\begin{array}{l}\text { EXPERIENCE } \\
\text { (divided by } 10 \text { ) }\end{array}$} & Ilaly & $\begin{array}{l}39 \\
(.03)\end{array}$ & $\begin{array}{l}.41 \\
(.04)\end{array}$ & $\begin{array}{l}.34 \\
(.03)\end{array}$ & $\begin{array}{l}.36 \\
(.02)\end{array}$ & $\begin{array}{l}.36 \\
(.03)\end{array}$ & $\begin{array}{l}.35 \\
(.02)\end{array}$ & $\begin{array}{l}.34 \\
(.02)\end{array}$ & $\begin{array}{l}.27 \\
(.02)\end{array}$ \\
\hline & U.S. & $\begin{array}{l}.45 \\
(.01)\end{array}$ & $\begin{array}{l}.43 \\
(.01)\end{array}$ & $\begin{array}{l}.42 \\
(.01)\end{array}$ & $\begin{array}{r}.43 \\
(.01)\end{array}$ & $\begin{array}{l}.45 \\
(.01)\end{array}$ & $\begin{array}{l}.44 \\
(.01)\end{array}$ & $\begin{array}{l}.48 \\
(.01)\end{array}$ & $\begin{array}{l}.46 \\
(.01)\end{array}$ \\
\hline \multirow{2}{*}{$\begin{array}{l}\text { EXPERIENCE } \\
\text { SQUARED } \\
\text { (dividal by } 1000 \text { ) }\end{array}$} & Italy & $\begin{array}{l}. .55 \\
(.05)\end{array}$ & $\begin{array}{l}-.56 \\
(.05)\end{array}$ & $\begin{array}{l}-.50 \\
(.05)\end{array}$ & $\begin{array}{l}-.50 \\
(.04)\end{array}$ & $\begin{array}{l}-.49 \\
(.04)\end{array}$ & $\begin{array}{l}-.48 \\
(.04)\end{array}$ & $\begin{array}{l}-.46 \\
(.03)\end{array}$ & $\begin{array}{l}-.36 \\
(.03)\end{array}$ \\
\hline & U.S. & $\begin{array}{l}-.70 \\
(.02)\end{array}$ & $\begin{array}{l}-.65 \\
(.02)\end{array}$ & $\begin{array}{l}-.63 \\
(.02)\end{array}$ & $\begin{array}{l}. .63 \\
(.02)\end{array}$ & $\begin{array}{l}-.66 \\
(.02)\end{array}$ & $\begin{array}{l}. .64 \\
(.03)\end{array}$ & $\begin{array}{l}. .69 \\
(.02)\end{array}$ & $\begin{array}{l}-.67 \\
(.03)\end{array}$ \\
\hline \multirow[t]{2}{*}{$<=$ ELEMENTARY } & Isuly & $\begin{array}{l}. .35 \\
(.02)\end{array}$ & $\begin{array}{l}-.39 \\
(.03)\end{array}$ & $\begin{array}{l}-.36 \\
(.02)\end{array}$ & $\begin{array}{l}-.37 \\
(.02)\end{array}$ & $\begin{array}{r}-.34 \\
(.02)\end{array}$ & $\begin{array}{l}-.34 \\
(.02)\end{array}$ &. .034 & $\begin{array}{l}-.32 \\
(.02)\end{array}$ \\
\hline & U.S. & $\begin{array}{r}-.39 \\
(0.1)\end{array}$ & $\begin{array}{l}-.41 \\
(0.1)\end{array}$ & $\begin{array}{l}-.41 \\
(0.1)\end{array}$ & $\begin{array}{l}-.41 \\
(0.1)\end{array}$ & $\begin{array}{l}. .46 \\
(0.1)\end{array}$ & $\begin{array}{l}. .42 \\
(0.2)\end{array}$ & $\begin{array}{l}-.47 \\
(0.2)\end{array}$ & $\begin{array}{l}-.47 \\
(0.2)\end{array}$ \\
\hline \multirow[t]{2}{*}{ JUNIOR IIIGII } & lually & $\begin{array}{l}-.21 \\
(.02)\end{array}$ & $\begin{array}{l}-.24 \\
(.03)\end{array}$ & $\begin{array}{l}. .23 \\
(.02)\end{array}$ & $\begin{array}{l}-.26 \\
(.02)\end{array}$ & $\begin{array}{l}-.23 \\
(.02)\end{array}$ & $\begin{array}{l}-.23 \\
(.02)\end{array}$ & $\begin{array}{l}-.23 \\
(.01)\end{array}$ & $\begin{array}{l}. .19 \\
(.01)\end{array}$ \\
\hline & U.S. & $\begin{array}{l}-.23 \\
(0.1)\end{array}$ & $\begin{array}{l}-.24 \\
(0.1)\end{array}$ & $\begin{array}{l}-.25 \\
(0.1)\end{array}$ & $\begin{array}{l}-.25 \\
(0.1)\end{array}$ & $\begin{array}{l}-.28 \\
(0.1)\end{array}$ & $\begin{array}{l}-.26 \\
(0.1)\end{array}$ & $\begin{array}{l}-.29 \\
(0.1)\end{array}$ & $\begin{array}{l}-.31 \\
(0.1)\end{array}$ \\
\hline \multirow[t]{2}{*}{ COLLEGE + } & Italy & $\begin{array}{l}22 \\
(.03)\end{array}$ & $\begin{array}{r}.14 \\
(.04)\end{array}$ & $\begin{array}{l}.18 \\
(.03)\end{array}$ & $\begin{array}{l}.15 \\
(.03)\end{array}$ & $\begin{array}{l}.27 \\
(.03)\end{array}$ & $\begin{array}{l}.21 \\
(.03)\end{array}$ & $\begin{array}{l}.16 \\
(.02)\end{array}$ & $\begin{array}{l}.26 \\
(.02)\end{array}$ \\
\hline & U.S. & $\begin{array}{l}.35 \\
(01)\end{array}$ & $\begin{array}{c}.32 \\
(.01)\end{array}$ & $\begin{array}{l}.32 \\
(.01)\end{array}$ & $\begin{array}{l}.33 \\
(.01)\end{array}$ & $\begin{array}{l}37 \\
(01)\end{array}$ & $\begin{array}{l}.39 \\
(.01)\end{array}$ & $\begin{array}{l}.43 \\
(.01)\end{array}$ & $\begin{array}{l}.43 \\
(.01)\end{array}$ \\
\hline \multirow[t]{2}{*}{$R \cdot s(j u: u r e$} & Itady & .23 & .24 & .25 & .26 & .29 & .23 & .27 & .23 \\
\hline & U.S. & .23 & .22 & .19 & .21 & .22 & .19 & .22 & .23 \\
\hline \#OBSERVATIONS & $\begin{array}{l}\text { Italy } \\
\text { U.S }\end{array}$ & $\begin{array}{c}1767 \\
22391\end{array}$ & $\begin{array}{c}1637 \\
22827\end{array}$ & $\begin{array}{c}1610 \\
27324\end{array}$ & $\begin{array}{c}2201 \\
23566\end{array}$ & $\begin{array}{c}2250 \\
22244\end{array}$ & $\begin{array}{c}2019 \\
22640\end{array}$ & $\begin{array}{c}3766 \\
23955\end{array}$ & $\begin{array}{c}3192 \\
23962\end{array}$ \\
\hline $\begin{array}{l}\text { AV. EARNINGS } \\
\text { (SUS) }\end{array}$ & $\begin{array}{l}\text { Italy } \\
\text { U.S. }\end{array}$ & $\begin{array}{c}6436 \\
15991 \\
\end{array}$ & $\begin{array}{c}7442 \\
17186 \\
\end{array}$ & $\begin{array}{c}8975 \\
18595 \\
\end{array}$ & $\begin{array}{c}7978 \\
22145\end{array}$ & $\begin{array}{c}7913 \\
23578\end{array}$ & $\begin{array}{r}7888 \\
24419 \\
\end{array}$ & $\begin{array}{l}10861 \\
27070\end{array}$ & $\begin{array}{l}13819 \\
28237 \\
\end{array}$ \\
\hline
\end{tabular}

Noles:

1) Dependent Variable $=\log$ of annual wage and salary cantings, full-time full-ycar nonagricultural workers who are sot self-employed age 18-65. Pre-hax in U.S., post-tax in ftaly.

2) Excluded cducation category = completed high scliool; All regressions also contain a constartL 3) Standard crrors in parentbeses.

Sources of Data: Banca Ditalin, U.S. Current Population Survey. 


\begin{tabular}{|c|c|c|c|c|c|c|c|c|c|}
\hline & & 78 & 79 & 80 & 82 & 83 & 84 & 86 & $\$ 7$ \\
\hline \multirow[t]{2}{*}{$\begin{array}{l}\text { EXPERIENCE } \\
\text { (divided by } 10 \text { ) }\end{array}$} & lanly & $\begin{array}{l}.30 \\
(.04)\end{array}$ & $\begin{array}{l}.27 \\
(.04)\end{array}$ & $\begin{array}{l}.23 \\
(.04)\end{array}$ & $\begin{array}{l}.24 \\
(.04)\end{array}$ & $\begin{array}{l}.19 \\
(.04)\end{array}$ & $\begin{array}{l}.20 \\
(.03)\end{array}$ & $\begin{array}{c}.28 \\
(.03)\end{array}$ & $\begin{array}{l}.18 \\
(.02)\end{array}$ \\
\hline & U.S. & $\begin{array}{r}.21 \\
(.01)\end{array}$ & $\begin{array}{l}.22 \\
. .01)\end{array}$ & $\begin{array}{l}.23 \\
(.01)\end{array}$ & $\begin{array}{l}.22 \\
(.01)\end{array}$ & $\begin{array}{l}.25 \\
(.01)\end{array}$ & $\begin{array}{l}.25 \\
(.01)\end{array}$ & $\begin{array}{l}.27 \\
(.01)\end{array}$ & $\begin{array}{l}.30 \\
(.01)\end{array}$ \\
\hline \multirow{2}{*}{$\begin{array}{l}\text { EXPERIENCE } \\
\text { SQUARED } \\
\text { (divided by } 1000 \text { ) }\end{array}$} & Italy & $\begin{array}{l}. .50 \\
. .09)\end{array}$ & $\begin{array}{l}. .45 \\
(.08)\end{array}$ & $\begin{array}{l}. .39 \\
. .08)\end{array}$ & $\begin{array}{l}-. .33 \\
(.08)\end{array}$ & $\begin{array}{l}.25 \\
. .09)\end{array}$ & $\begin{array}{l}-.29 \\
(.06)\end{array}$ & $\begin{array}{l}\cdot .43 \\
(.05)\end{array}$ & $\begin{array}{l}. .24 \\
(.05)\end{array}$ \\
\hline & U.S. & $\begin{array}{l}. .34 \\
(.03)\end{array}$ & $\begin{array}{l}-. .36 \\
(.02)\end{array}$ & $\begin{array}{l}-.36 \\
(.02)\end{array}$ & $\begin{array}{l}. .36 \\
(.03)\end{array}$ & $\begin{array}{l}-.42 \\
(.03)\end{array}$ & $\begin{array}{l}. .42 \\
(.03)\end{array}$ & $\begin{array}{l}.44 \\
(.03)\end{array}$ & $\begin{array}{l}.50 \\
(.03)\end{array}$ \\
\hline \multirow[t]{2}{*}{$<=$ ELEMENTARY } & Italy & $\begin{array}{l}-.44 \\
(.04)\end{array}$ & $\begin{array}{l}. .50 \\
(.04)\end{array}$ & $\begin{array}{l}-.43 \\
(.05)\end{array}$ & $\begin{array}{l}-.49 \\
(.04)\end{array}$ & $\begin{array}{l}-.43 \\
(.04)\end{array}$ & $\begin{array}{l}-.44 \\
(.04)\end{array}$ & $\begin{array}{l}. .42 \\
(.03)\end{array}$ & $\begin{array}{l}. .39 \\
(.03)\end{array}$ \\
\hline & U.S. & $\begin{array}{l}-. .37 \\
(.02)\end{array}$ & $\begin{array}{l}. .35 \\
(.02)\end{array}$ & $\begin{array}{l}-.40 \\
(.02)\end{array}$ & $\begin{array}{l}. .40 \\
(.02)\end{array}$ & $\begin{array}{l}-.40 \\
(.02)\end{array}$ & $\begin{array}{l}. .38 \\
(.02)\end{array}$ & $\begin{array}{l}. .42 \\
(.02)\end{array}$ & $\begin{array}{l}. .45 \\
(.02)\end{array}$ \\
\hline \multirow[t]{2}{*}{ JUNIOR HIGH } & Inaly & $\begin{array}{l}. .22 \\
(.04)\end{array}$ & $\begin{array}{l}. .21 \\
(.04)\end{array}$ & $\begin{array}{r}.13 \\
(.03)\end{array}$ & $\begin{array}{l}.17 \\
(.03)\end{array}$ & $\begin{array}{l}-.20 \\
(.03)\end{array}$ & $\begin{array}{l}. .21 \\
(.03)\end{array}$ & $\begin{array}{l}-.21 \\
(.02)\end{array}$ & $\begin{array}{l}. .20 \\
(.02)\end{array}$ \\
\hline & U.S. & $\begin{array}{l}. .25 \\
(.01)\end{array}$ & $\begin{array}{l}. .22 \\
(.01)\end{array}$ & $\begin{array}{l}-.23 \\
(.01)\end{array}$ & $\begin{array}{l}-.27 \\
(.01)\end{array}$ & $\begin{array}{l}-.28 \\
(.02)\end{array}$ & $\begin{array}{l}-.25 \\
(.02)\end{array}$ & $\begin{array}{l}. .29 \\
(.02)\end{array}$ & $\begin{array}{l}. .31 \\
(.02)\end{array}$ \\
\hline \multirow[t]{2}{*}{ COLLEGE + } & laaly & $\begin{array}{l}.08 \\
.055\end{array}$ & $\begin{array}{l}.08 \\
. .05)\end{array}$ & $\begin{array}{l}.13 \\
(.05)\end{array}$ & $\begin{array}{l}.15 \\
(.04)\end{array}$ & $\begin{array}{l}.18 \\
\text { (.01) }\end{array}$ & $\begin{array}{l}.13 \\
(.03)\end{array}$ & $\begin{array}{l}.12 \\
(.03)\end{array}$ & $\begin{array}{l}.14 \\
(.02)\end{array}$ \\
\hline & U.S. & $\begin{array}{l}.36 \\
(.01)\end{array}$ & $\begin{array}{l}.36 \\
(.01)\end{array}$ & $\begin{array}{r}.38 \\
(.01)\end{array}$ & $\begin{array}{c}.36 \\
(.01)\end{array}$ & $\begin{array}{c}.38 \\
(.01)\end{array}$ & $\begin{array}{r}.39 \\
(.01)\end{array}$ & $\begin{array}{r}.43 \\
(.01)\end{array}$ & $\begin{array}{r}.45 \\
(.01)\end{array}$ \\
\hline R-square & $\begin{array}{l}\text { Italy } \\
\text { U.S. }\end{array}$ & $\begin{array}{l}.16 \\
.16\end{array}$ & $\begin{array}{l}.21 \\
.16\end{array}$ & $\begin{array}{l}.15 \\
.15\end{array}$ & $\begin{array}{l}.17 \\
.15\end{array}$ & $\begin{array}{l}.17 \\
.15\end{array}$ & $\begin{array}{l}.20 \\
.14\end{array}$ & $\begin{array}{l}.19 \\
.16\end{array}$ & $\begin{array}{l}.21 \\
.18\end{array}$ \\
\hline HOBSERVATIONS & $\begin{array}{l}\text { Inaly } \\
\text { U.S. }\end{array}$ & $\begin{array}{c}838 \\
12204\end{array}$ & $\begin{array}{c}820 \\
12999\end{array}$ & $\begin{array}{c}829 \\
16055\end{array}$ & $\begin{array}{c}1104 \\
14886\end{array}$ & $\begin{array}{c}1101 \\
14981\end{array}$ & $\begin{array}{l}1073 \\
15547\end{array}$ & $\begin{array}{c}1991 \\
16493\end{array}$ & $\begin{array}{c}1797 \\
16507\end{array}$ \\
\hline $\begin{array}{l}\text { AV. EARNINGS } \\
\text { (SUS) }\end{array}$ & $\begin{array}{l}\text { Ituly } \\
\text { U.S. }\end{array}$ & $\begin{array}{l}4787 \\
9242\end{array}$ & $\begin{array}{l}5683 \\
10051\end{array}$ & $\begin{array}{c}7072 \\
10936\end{array}$ & $\begin{array}{l}6216 \\
13198\end{array}$ & $\begin{array}{l}6321 \\
14397\end{array}$ & $\begin{array}{l}6129 \\
15265\end{array}$ & $\begin{array}{l}8395 \\
17226\end{array}$ & $\begin{array}{l}10684 \\
18128\end{array}$ \\
\hline
\end{tabular}

Noles:

1) Dependent Variable $=\log$ of annual wage and salary eamings, full-ume full-ycar nonagricultural workers who are not self-employed age 18-65. Pre-tax in U.S. post-tax in lialy.

2) Excluded education category = completed high school; All regressions also contrin a constine

3) Stanchud errors in parenteses.

Sources of Ditn: Banca D'lialia, U.S. Current Population Survey. 
Third, making willin-gender comparisons across ule two countrics: in cach period. the returus to high selvool and college are higher and uxe experience-carnings profile is stecper for American men than for laalian men (cxcepting the retum to completing liglt sclwol relative to completing junior hight in 1982). While Italian women begin with stecper experience-carnings profiles and a greater carnings deficit at the lowest celucational catcgory compared to Anerican wonen. these relationships are reversed by the end of the period after the greater growth in returns to culucation and experience anong American wonen (the return to a college degree is much greater for American wonken than Italian woncn throughout, but the gap is larger at the end of the period).

Finally, making within-country comparisons across the genders: American men and women lave roughly similar returns to high school and college, while Italian wormen have a greater retum to a high school degree than Italian men when the comparison group is clenentary or less, and Italian men have a somewhat greater return to college.

\section{IIl.4 Oycrall Eamings Incquality}

The trends in overall inequality are shown in Table 10, which displays five measures of carnings incquality for men and women: the $90 \%$ - $10 \%$ log camings differential, uhe $90 \%-50 \%$ $\log$ earnings differential. the 50\% - $10 \%$ log carnings differential, the standard deviation of log cartungs. and the standard deviation of log earnings residuals from separate regressions by genderyear-country cells (i.c. the regressions presented in Tables 8 and 9), as well as the standard deviation of $\log$ carnings for men in industry in Italy and manufacturing in the U.S. In all cases but the 50-10 differential for wonken in the carlier years incquality is greater for Antericans than for Uxeir Italian gender counterparts. In all but one casc, there is evidence of an increase in incquality in the U.S. and somewhat weaker evidence of a decrease in inequality in Italy - the exception is the $90 \%-50 \%$ log earnings differential for men in italy, which increases steadily after 1979.27

27 This suggests that for men Italian labor market institutions may have sucoceded in kecping up wages at Ule bottom but not in preventing substantial wage drift at the top. The same does not seem to be toue for wounen. Note as well that the $90-50$ differential is greater for Italian men than for lalian women, pertaps reflecting the grealer returns to a college degree for men in laly, while most other measures of incquality are greater for Italian women than for Italian men 
TABLE 10 MEASURES OF INEQUALITY OF LOG EARNINGS, ITALY AND U.S.

\begin{tabular}{|c|c|c|c|c|c|c|}
\hline \multicolumn{7}{|l|}{ ITALIAN } \\
\hline Lear & $\frac{20-10}{\text { differential }}$ & $\frac{90-50}{\text { differential }}$ & $\frac{50-10}{\text { differential }}$ & $\begin{array}{l}\text { Slandard } \\
\text { devialion }\end{array}$ & $\begin{array}{l}\text { Stand.der: } \\
\text { of residuals }\end{array}$ & $\begin{array}{l}\text { Shondader } \\
\text { in Indusiox }\end{array}$ \\
\hline 1978 & .827 & .470 & 357 & .402 & 353 & .409 \\
\hline 1979 & .742 & .336 & .405 & .410 & 358 & .420 \\
\hline 1980 & .742 & 377 & 365 & 367 & 319 & .377 \\
\hline 1982 & .762 & .405 & .357 & 373 & 320 & . 387 \\
\hline 1983 & .724 & 361 & 363 & 370 & 311 & .364 \\
\hline 1984 & .693 & 379 & 314 & 374 & 328 & 333 \\
\hline 1986 & .729 & .419 & 310 & .337 & 288 & 317 \\
\hline 1987 & .734 & .446 & .288 & 355 & 311 & .371 \\
\hline
\end{tabular}

\begin{tabular}{|c|c|c|c|c|c|c|}
\hline \multicolumn{7}{|c|}{ AMERICAN MEN } \\
\hline$x \cos x$ & $\frac{20-10}{\text { differential }}$ & $\begin{array}{c}20-50 \\
\text { differential }\end{array}$ & $\frac{50 \cdot 10}{\text { differencinl }}$ & $\begin{array}{l}\text { Standard } \\
\text { devintion }\end{array}$ & $\begin{array}{l}\text { Shand dex } \\
\text { of residuals }\end{array}$ & $\begin{array}{l}\text { Shand ulce } \\
\text { in Industoy }\end{array}$ \\
\hline 1978 & 1.206 & 533 & .672 & .531 & .466 & .471 \\
\hline 1979 & 1.216 & .549 & .668 & 535 & .473 & 512 \\
\hline 1980 & 1.261 & 565 & .696 & 578 & 522 & 509 \\
\hline 1982 & 1.257 & 564 & .693 & 564 & 502 & .520 \\
\hline 1983 & 1.348 & .606 & .742 & 586 & 516 & .518 \\
\hline 1984 & 1.379 & 598 & .781 & .632 & .570 & 543 \\
\hline 1986 & 1.409 & .629 & .780 & .638 & .563 & .575 \\
\hline 1987 & 1.452 & .631 & .821 & .627 & .549 & 582 \\
\hline
\end{tabular}

\begin{tabular}{|c|c|c|c|c|c|}
\hline \multicolumn{6}{|l|}{ TALLINN } \\
\hline year & $\frac{90-10}{\text { differenlial }}$ & $\begin{array}{c}20-50 \\
\text { differential }\end{array}$ & $\frac{50-10}{\text { differential }}$ & $\begin{array}{l}\text { Standard } \\
\text { deriation }\end{array}$ & $\begin{array}{l}\text { Shandeder } \\
\text { of residunks }\end{array}$ \\
\hline 1978 & .916 & .336 & 580 & .447 & .408 \\
\hline 1979 & .869 & .256 & .613 & .437 & 388 \\
\hline 1980 & .787 & 288 & 500 & .435 & .400 \\
\hline 1982 & .867 & .342 & 525 & .447 & .407 \\
\hline 1983 & .860 & 314 & 547 & .427 & 388 \\
\hline 1984 & .693 & .241 & .452 & 371 & 330 \\
\hline 1986 & .818 & .268 & s50 & .398 & 358 \\
\hline 1987 & .693 & .251 & .442 & 343 & 305 \\
\hline
\end{tabular}

\begin{tabular}{|c|c|c|c|c|c|}
\hline \multicolumn{6}{|c|}{ MERICAN WOMEN } \\
\hline year & $\begin{array}{c}90-10 \\
\text { differential }\end{array}$ & $\begin{array}{c}90-50 \\
\text { differentinal }\end{array}$ & $\frac{50-10}{\text { differential }}$ & $\begin{array}{l}\text { Standard } \\
\text { deriation }\end{array}$ & $\begin{array}{l}\text { Sinnd der } \\
\text { of resichials }\end{array}$ \\
\hline 1978 & 1.082 & 548 & 535 & .484 & .443 \\
\hline 1979 & 1.124 & 568 & 556 & .472 & .433 \\
\hline 1980 & 1.054 & .543 & 511 & .514 & .473 \\
\hline 1982 & 1.099 & 560 & 539 & 510 & .471 \\
\hline 1983 & 1.161 & 571 & 591 & 532 & .491 \\
\hline 1984 & 1.204 & 580 & .624 & 548 & 507 \\
\hline 1986 & 1.253 & .616 & .636 & .556 & 509 \\
\hline 1987 & 1.322 & .629 & .693 & 564 & $s 11$ \\
\hline
\end{tabular}

Sources of Data: Banca D'lialia, U.S. Current Population Survey. 
We do not have a conclusive explanation for the lack of a U-shape in Italian individuallevel inecpuality which we see in the agaregate sectoral data presented in the previous two sections. One possible cxplanition is that the consposition of our sample of individuals may lead to results witicls do not reflect the changes in metal-manufacturing inter-inquadramento incquality, or the other neasures of incer-industry and inter-occupational incquality presented above. Less than $50 \%$ of the BDI sampic (substantially less for women) are cmployed in industry, and when we analyze this sector separately, we do find a rise in the standard deviation of log camings for nen in 1987 to a level above that in 1983, 28 though it still drops from 1983 through 1986 (final colunin of Table 10). Anotluer possibility is that "industry" contains sectors which had a different experience than metal-manufacturing: unfortunately, we cannot separate out these other sectors in this data set.

III.5 Possible Explanations for the Divergent Trends in Ovcrall Inceuality in lialy and the Uniled Slaics

We recogivize thiat there are many conceivable explanations for these divergene results on the coefficients in the carnings functions and the dispersion of carnings in the two countries. These range from differences in tochnology (or the relationship of earnings and productivity within individual firms), to differenoes in the inbalances betwoen the supply and demand for skills (including the effect of the price of cducation on labor supply, college being virtually frec in ltaly). to the possibility of different methods of non-price rationing in the labor markets (including various types of discrinuination), to the changing influence of taxes (which are nelled from the ltalian but not the U.S. data).

We certainly cannot distinguish definitively among these alternatives at this point. Yct. because we find uxe difference in the trends of inequality to be so striking, we close this section by exanining some possible explanations for the novement toward rising incquality in the U.S. and stable-10-falling incequality in ttaly, as displayed in Table 10. An explanation which is logically possible involves the distribution of skilis in the two countrics: the above results might be consistent with a sharper trend toward higher educational attainment anjong fully cenployed workers, and thus loward greater overall inequality in the U.S. Recall, lrowever, from the discussion above (Table 6) that while the average levels of education are higles in the U.S.. the trends in educational attainment secm to be guing in the same basic directions in the two countries in fact, the proportion of fully cmployed workers with college degrees or more las increased ntore sharply in Italy than in the U.S. for both men and womer 29

28 The sample of women in industry is 100 small to be reliable.

29 On the other hand, a given increase in the proportion of college edueated workers miglt be expected to produce more overall inequality in the U.S., given the generally higher retums to schooling. 
The findings on the trends in inequality could also be consistent will differential changes in the occupational or industrial structures in the two countries. In fact, the share of blue collar workers has been falling and the share of white collar workers rising for both nen and wonen in the Italian simple: the sluare of blue collar workers among men fell from 59\% in $19781049 \%$ in 1986 while the stare of white collar workers rose from 41\% to 51\%; among women, Uue sliare of blue collar workers fell from 49\% in 1978 to $40 \%$ in 1986 and the share of whice collar workers rose from $50 \%$ 10 60\%.30 As for the industrial distribution. the calcgory "industry" is the largest anong men, but has dropped over this period from $48 \%$ of the workers in 1978 to $39 \%$ in 1986 . while use calcgorics "public administration" and the residual category have been growing. Among

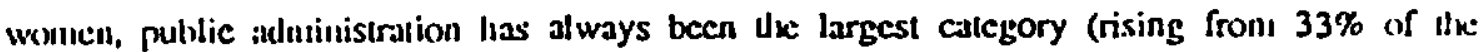
workers in 1978 (o) $43 \%$ in 1986), and has also grown relative to industry: trade is the third-1:urgesi

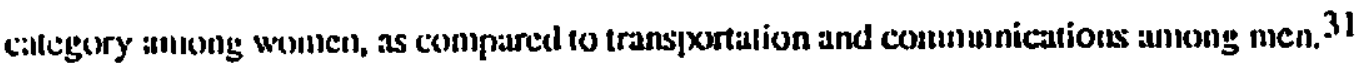

Overall, lien, there lias been a shiff away from hlue collar and industrial jobs and a shift loward whice collar and public administration jobs among both men and wonen in lialy over llis period. The industrial and occupational categories are not strictly comparable with those in the CPS, so we do not present a direct comparison. but these results suggest that Italy has heen undergoing a de-industrialization similar to oher Western countries. indicating that uxe explanation for the divergence of the trends in incquality will probably not be found here.

Furthermore, when we calculate the effects of between-industry shifts in labor demand on the relative demands for different skill and gender groups in Italy (using the methodology of Katz and Murphy 1992 and Kalz, Loveman and Blanchllower 1993, who find cvidence of slufis toward more educated workers in the U.S. and elsewhere), based on six industries and six gender-skill groups, we find a shift against workers will less than a high school degrec, a slight sluft in favor of workers who completed high school, and a much greater shift toward workers with a college degree or more for bout men and women. 32 We conclude that the fall in retums to high school, the less.

30 This is consistent with the findings for the metal-manufacturing soctor presented in section II, ahove.

31 Nexe that we use 1986 for the ending date bere because die industrial and oxcupationit classification systeurs clasuge in 1987.

32 "The six industries are "industry," "public administration," "urade," "public transport ant

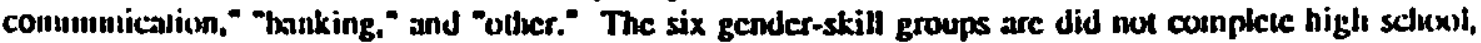
completed high seliool, and college degree for inen and wernen. We use 1978 as die hase yess aud 1986 as the cruding year due to dic change in the occupational ctassification systean in 1987. The value of the shift away from men who did not complete high school, as measured by the difference in the logarithons of the indexes of relative demands from 1978 L 1986, is -.132, toward men who completed bigh school .095, loward inen with a college degree .158, away from womes who did not complete high school -.003 , loward woinen who completed high school .172, toward women with a college degree 253. 
than-dramitic rise in the returns to college, and the drop in overall inequality in Italy are not due to between-indusury slufts in labor deniand away from more educated workers. 33

The influence of taxcs, which are netted from the Italian data but not from use U.S. data is another candidate explanation for the observed trends in inequality in ttaly and the U.S. The lialian tax sy'stem is effectively progressive both because of the structure of marginal tax rates and ux lump-sum nature of deductions. While pre-tax eamings have been found to be more unequal than post-lax carnings, the progressivity of the tax system scems to have decreased between 1982 and 1987.34 Thus suggests that while une influence of taxes nught contribute to the difference in une level of inequality in the two samples, it probably does not drive une difference in the trends; if anything. we would expect a bias toward increasing incquality in ltalian post-tax carnings from the decreasing progressivity of the ltatian tax structure over this period.

One additional pessibilitity that we litul appenling is that differences in the nature and crolution of labor market institutions in the two countrics have conbrilsuted to the low and filling incquality in ltaly and use high and rising incquality in une U.S.- specifically, lalsor niarket institutions (union contracts and relatively centralized bargaining structures, for example) act to narrow carnings inequality to a greater extent in Italy and have nol been deregulated or otherwise dismantled to the extent they have been in the U.S. This final interpretation is consistent with the generally lower returns to a college degree and the less steep experience-camings profiles in ltaly, as well as the general thrust of the evidence provided in section II on the metal-manufacturing secior.

V Conclusions: Mechanisms Outside the Regular Economy Influcncing Overall Italian Wage Inequality

The overall picture of Italy presented in this chapter is of a country with a conpressed wage structure which is not yet undergoing the rapid decompression experienced clscwinere during the 1980s. Thie doctine of inter-inquadramento, inter-industry and blue collar / white collas differentials during unc 1970s came to a stop and was slightly reversed during the 1980s, but these

33 The evidence on ule growth of clucational calegories within industries is somewhat more mixed: while the share of workers with a high school degrec or above rises or remains stable between 1978 and 1986 in every industry except the residual "other", the share with a college degree actually falls stightly in three industries: "public adtrinistration," "banking," and "oulver." This suggests that thene may not have been increases in the demand for skilked workers within these industries; keep in unind, however, that "public adninistmion" and "banking" ane boch relatively politically controltal, so that their hiting practices many be driven by concerns other than the technological noeds for skills (political patrounge, for example).

34 Sec Nardecchia and Patriarca 1992, Ricciardelli 1992 and Di Bella and Parisi 1992. 
differentials did not rise back to the pre-1980s levels despite the reforms of the nuid-19SOs. Over the 1978-1987 period, neasures of individual-level carnings incquality indicatc, if anything, a trend toward a less uncqual distribution. This trend is in marked contrast to the experience in the U.S., where inequality clearly increased during the i980s.

Thierc seem to lave been three important determinants of Ulis evolution of wage differestials in Italy over the last twenty years. First, the eqalitarian idedogy of Italian unions, which in times of union strength such as the 1970 s led to the institutionalization of equalizing practices such as low contracted wage differentials and cgalitarian escalator clauses. Second, une dynamic of infation in conjunction with the different escalator regimes that laly has experienced during this period. Third, the evolution of technology, productivity differentials and related skill shonages in ule labor markets, which nost likely primarily influenced the individually-contracted portion of total compensation.

One night have expected that the clear bresk in the evolution of wage differentials around 1982-83 would have offered the chance to evaluate the relative imporance of these factors. However. the simulaneous nature of Uhese processes makes such a task impossible with the available information: the years when the compression of wage differentials came to a stop. or at lcast 10 a slowdown, were also the years in which major discontinuities occurred in the cvolution of Whe three factors identificd above: union strength, as measured by strike activity and by membership. significantly weakened; inflation, after the explosion of the 1970s, stirted a downward trend that lasted until the late 1980s; and, finally, the process of industrial restructuring induard by the oil shocks and by the computer revolution likely caused changes in the denlanked skill composition of the labor force, not necessarily and not immodiately matched by changes in uxe composition of supplics.

Nevertheless, the evidence provided by the comparison with the U.S. suggests that the continuing compression in the regular sector is likely not attributable to market forces. Both countrics appeir to have experienced the sort of tsend toward a more cducated and more hesvily white collar workforce that accompanies de-industrialization. In addition. the analysis of betweenindustry labor denand shifts provides no evidence of a shift away from more educated workers in cither coluntry. Despitc tuese similar labor supply and labor desnand indicators, measured inequalily has been relatively high and increasing in the U.S. and low and decreasing in ltaly. Thius, there secns lo be room cnough for alternitive explanations for the italian case.

It is difficult to deny that cgalitarian institutions, and in particular the scala mobilc, bore large responsibility for Ule wage compression of the 1970s. We cannot say how much of that compression was actually expected in 1975 when the scala mobile payments were first equalized across all workers; most likely, the probability of many years of inflation in double figures was 
underestimaled at Uat time. 35 Indecd, Uhe fact diat contracted differentials started to increase in 1979. leaving indexation as Uhe primary facior causing compression Ulrough 1983, suggests Uiat unions night have realized Uat Uxe compression was beconing excessive. Yet, Uhe 1975 sysicm was not modificd until 1983 and only in 1986 was its cgalitarian nature substantially clıanged. The fact Uat it took so long to reform Uxe scala mobile leads to Uxe suspicion that the implicd compression was not too far from what ule market could bear. On the other hand, cpisodes tike the march of Uhe 40,000 in 1980 and the referendum against Ure scala mobile in 1985 suggest that Uhe compression had already reached the threshold of sustainability by Ule carly 1980s, and indecd in subsequent years the system was changed.

Before une reform of the scala mobile, the individual superminimum was ure cscape valve Utrough wluch Uxe parties could make bearable Uxe compression caused by inflation. One nuight even suspect Uhat the discqualizing effect of Ure drift was part of some lind of implicit agrecment between employers and unions to control the compression caused by unexpectedly high inflation. Unions might have been attached to the egalitarian scala mobile for internal political reasons, allowing the drift to correct for the unexpected effects. However, we do not have evidence on the validity of Uxese speculations, and if they were truc, one would be left with Uhe ruestion: why wasn't Ure excessively egalitarian nature of the escalator sysecm reformed before ule mid-1980s, if cven Ule majority widuin the unions may lave teen dissatisficd will it?

Indecd, if the system had been modificd by giving more weight to contracted increases, as for example in Sweden, 36 unions might have acquired more control over wage delermination and uage dispersion. Bul, preciscly the comparison with the Swedish experience suggests that Uxe instrument Uurough which compression is achicved (escalator in Italy. contracted increases in Sweden) is probably irrelevant what matters is the extent to which compression can be inposed. and in both countries the sustainable Ulreshold was reached around the same period.

Why, Uien, were employers unable to undo the compression? For employers, individual superminima were not a costless instruncent for controlling wage compression: given the compensation increases granted by the contracts and by the scala mobile to low inquadramento levels, larger superminima at high levels implicd a greater growth in total labor costs. Thereforc, Ule discyualizing potential of individual superminima was sontewhat linited by constraints on total labor cost increases. These constraints were likciy to have been particularly binding during unc

35 Franco Mattei, one of the Confindustria experts who bargained the 1975 agrecment wrote afterwards: "The compression effect of Ule new system was perceived, but it was considered as justified in the short period emergency [to protect low wages from Uhe oil shock inflation]. Even myself, looking back at iny notes, in November 1974 I did not expoct that we would have had an inflation rate around $20 \%$ for so many years. I thought that we were at a peak of infation but that inhation was soon going to be climinated." (Mattci 1981, 141).

36 Sec Edin and Holmlund 1993. 
period of lugh inflation, and tuis niglu explain why the individual superminima did not fully offset the effect of the scala mobile before 1983. Yet, the puzze remains as to why wage incquality did sot increase back to its levels of the early 1970s after inflation slowed dou'n, particularly wfien technological clanges probably required, if anything, a more marked trend toward larger compensation differentials across skills, as wecurred in the U.S. and elsewhere.

A credible partial explanation to this puzzle is that ouner renedies to wage compression, perhaps less costly to employers, seem to have proliferated in the non-regular areas of the cconomy, not covered by our empirical analysis above. For example, Italy is anong the developed countries with the greatest levels and highest recent growth rates of self-enployment: nonagricultural self cmployment as a proportion of total civilian cmployment grew from $18.9 \%$ in 1979 to 22.3\% in 1990 (OECD 1992). 37 ltakian sclf employment may be a consequence of the presence of restrictive labor market regulations imposed by unions, in particular liring and firing costs (Bertola 1990). It is also possible that ute compression of wage differentials for non-self employed workers might lave spurred the diffusion of self employment: some of the high skilled workers who saw their earnings limited by the egalitarian union policies may have offered theniselves as freelancers (perhaps even to the same firms that were previously hiring then as enployees) with the aim of getting better returns to their skilts. Though we are not aware of any explicit quantitative evidence on this link between wage compression in the unionized sector and self employment, it secnis to be a credible hypothesis, consistent with ancedotal evidence. If this is the case, then Ule egalitarian efforts of unions have been only parially successful: wages of regular employecs may lave been compressed, but an increasing number of workers could bave avoided uhe compression by joining self employment.

Italy is also well known for having a large underground economy and, almost by definition. the underground economy is something over which official wage-setting institutions and unions lave no legal control and minimal influence. As in the case of self employment, one is tenpted to ittribute lie size of uxe underground cconomy to the existence of labor market and fiscal regulation that enployers view as burdensome. Indeced, the available estimates of the underground cconomy for Italy are larger than most cstinates for other westem countries, where labor market regulations are generally less restrictive (Dallago 1988; Dallago 1990). 38 In line with this view, the

37 As a point of comparison, the share of self employed workers grew from $7.1 \%$ in 1979 to $7.6 \%$ in 1990 in the U.S. The U.K seems to be the counery with the greatest growth of the proporion uf scif cmpluyed, from 6.6\% in 1979 to $11.6 \%$ in 1990 . The sthare of self-enployed worters in ute complete Bank or taly survey rises from 17.5\% in 1978 to 23\% in 1987; ue do not use these observations for the wage inequality ealculations in section III because we have no way of distinguishing full-time selfempluyed fron part-lime.

38 Dallago 1988 repors that receat estimates of the Italian underground GDP as a pruportion of totil GDP range from 6\% $1030.1 \%$, with most estimates in bouble ligures. For the U.S.. the analogous 
compression of wage differentials in the unionized sector could he a stimulant for the underground conomy: if some of the compression is achieved by raising low wages (an hypothesized effect of the scala mulvile), it becomes difficult for employers to proftably maintain "overground" activities invalving less stilled workers. Though hiring less skilled workers into underground activities $1 \mathrm{kx}$ controlled by unions may be infeasible for large companics, the reader should kecp in mind that the lalian productive structure is constituted in large part by very smalt firms.

Yet. in contrast to self employment, it is difficult to find any reliable evidence of a significantly increasing trend in the underground cconomy in lialy in recent years. While the lack of reliability is no doubt in large part inherent in any attempt to measure underground activitics. Ure official statistics that do cxist (a revised series of tialian GNP from the central statistical office, ISTAT) show that the non-explicilly measured portion of national product went from $15.3 \%$ in 1980 to $17.7 \%$ in 1985 and then slightly decreased to $16 \%$ in 1986 (Dallago 1988, 73-75). 39 It thus seenis more difficult than in the situation of self employment to build a prima facie case for a link between uxe trend in the compression of wage differentials and possible diffusion of uxe underground cconomy

Another manner in which a de facto wider wage distribution may have been achieved despite the compression documented above involves the so called Contrati di Formazione $e$ Lavoro: special labor contracts for workers between 14 and 29 years of age. Permancnily introduced by law in 1984 after several pxevious experiments, they require employers to provide some training in return for lower wages and social contributions. In contrast to standard jobs, the contracts are temporary (24 ntonths); at the expiration of the contract, the comployer can decide whether to hire the worker for a lifetine position without having to consider other unemployment queues, and financial incentives for transitions into permanent contracts are provided by the government. The number of young workers hired under these contracts grew from 10.694 in 1984 to 529.297 in 1989. The biggest jump was between 1986 and 1987 when the number of hirings grew from 229.126 to 402.586; this jump was influenced by a nodification to the law providing cmployers with larger wage and social contribution savings. The number of new Contrati di Formazionte e Lovoro has started to slightly docline only recently, down to 469,050 in 1990.40 The available data indicatc that approximately $50 \%$ of these contracts (40\% in the south) are eventually trunsformed into permanent contracts (Ministero del Lavoro 1988-1991).

The popularity of Uxese contracts among both young workers and employers is consistent with the view that a less compressed wage distribution is weloomed by both groups (possihly at the

estimales sange from $26 \%$ to $33 \%$, with very few estimales in double figures. See also Deaglio 1984 and Rey 1985 for furdier discussion of the ladian underground econtony.

39 Note, liowever. Utat only a part of this change is attributable to the actual growdi of the 40 underground economy; the rest is due to a revision in statistical techniques.

40 This amounts to approximately $3 \%$ of the total non-agricultural paid workforce. 
expense of unemployed older workers who would have to be hired under standard permanent coneracts), particularly given the oft-stated charge that unese employment relationships to and really serve ulcir official function of providing young workers with nxeaningful special training. From the employers' point of view the advantages are fairly obvious, but uxese contracts are likely (1) represent a desirable alicrnative to unemployment or to employnent in the underground economy for the young workers as well. Youlh unemployment has been relatively hight in thaly in recent years: the percentage of total unemployment constituted by job seckers between the ages of 14 and 24 fluctuated around 61-62\% between 1978 and 1983. declining thereafter to $54 \%$ in 1987 and to 48\% in 1990 (OECD 1978-1990). Most likely, many of these young workers have been finding jobs in the underground cconomy. But even if the amount of underground cmployment hidden in the official youth uncmployment figures is significant, the basic conclusion we draw from this evidence is unchanged: it seems that by imposing their egalitarian aspirations on the regular sector of the economy, Italian unions may have ended up limiting the size of this sector.

The evidence we present in the first three sections of this chapter indicates that wage differentials have indecd been compressed in the regular sector of the ceonomy. Yel, whis concluding section suggests that this very compression may well have contributed to the llight away from the regular sector at both ends of the skill distribution: high skilled workers may have Ieft to seck the unrestricted retums to self employment, while less skilled entrants were induced (t) accept lower paying training contracts, were forced into the more precarious underground conomy, or remained uncmployed. These mechanisms may well, in tum, have contributed to a greater overall degree of inequality than is apparent in our analysis of wage differentials in ux: regular sector of the Italian economy. 


\section{DATA APIENDIX}

\section{$\triangle S S O L O M B A R D A$}

Assolombarda is the association of private employers in the Lombardy region. The data set is based on a survey of the associated firms in the Milan area. The survey las been taken in October and April of each year since 1976, but not all of the surveys, particularly at the beginning of the simple, are avilable. For each firm and inquadramento-level cell the survey provides the average of each compersation component received by the workers in that cell; individual firms cannot be identified, however. In 1988 there was a change in the design of the survey, but for the netal-manufacturing sector (the one we analyze), previous data lave been readjusted by Assolombarda to ensure coniparability across years. We are, lowever, less than fully confident about the consistency of these readjustments, since some apparent discontinuitics lave not been clininated: therefore. we use cross time coinparisons in this data set only when the regularity of une data secnis acceptable.

We have access to firm-level information only for the Oclober surveys from 1983 through 1990. For the other years we rely on the publislied averages across fimis for each inquadrancnto level.

\section{BANCA DTTALIA}

The Bank of lialy survey of ltalian houscloolds was first collected in 1977. In 1985 unc survey was not done and the data for 1981 are not considered to be sufficiently representative by the cxperts at the Banca D'talia. Post-1987, the survey is being conducted bi-aunually.

Data are collected on a representative cross- section of Italian houscholds by a privatc company for the Banca D'talia. The survey has been mainly designed to provide information on consumption and savings belavior; therefore, the infornation available for the cstimation of c:urnings functions and in gencral the information avalable for labor market rescarcl is somewlat linuted.

Sec also: Banca D'Italia, "I bilanci delle faniglic Italianc". in Supplenienti al Bollettino Statistico. Notc metodologicle e informazione statistiche., various years; and Banca d'lialia, "Le indagini campionaric sui bilanci delic famiglic italianc'. Nuncro speciale dej Contributi all'analisi cconomical, 1986.

\section{TEDERMECCANICA}

Federmeccanica is the uational association of private metal-manufacturing firms. "this datta set is based on a sample of tre assuciated firms and provides, for each incpradrauseuto level, the cross-firm average total monthly conupensation and the cross-fim average contractual plus scala 
mobilc compensation. It also provides the proporion of workers in each inquadrumento level. Dala are available from 1976 through 1990.

\section{MINISTERO DEL LAVORO}

This data set is based on a survey of 11,000 plants and is sponsored by the Minister of Labor. Until 1977, only firms with more than 5 employees were included. Post-1977. Ure survey is limised to firms with more than 50 employecs.

The data used in figure 1 is the average hourly bluc collar and trainees' compensation, computed as the total nonthy base compensation paid to these workers divided by the fotal number of hours. The series was discontinued in 1985. A new series was started in 1986 but the data are not yet available.

\section{NATIONAL ACCOUNTS}

We lave used the New Scries (1970-1989) of the National Accounts data published by ISTAT (Istituto Nazionale di Statistica), Collana di Informazjone, edizione 1990, n 10. 


\section{REFERENCLS}

ASAP Unita' Studi 1986-1991, Rapporto sui salari. Milano: Franco Angcli.

Alleva P.G. 1986, "Legislazione c contraltazione colletliva nel 1985-1986.", Giomale di Diritto del Laioro e di Relazioni industriali, n.31, pp. 611-664.

Bertola G. 1990, "Job Security, Enployment, and Wages", European Economic Review, n. 34, pp.851-886.

Biagioli M. 1985. "Contrattazione aziendale c differenziali retributivi." IRES Papers, n.1, pp.1-61. 19S8, "I differenziali retributivi interprofessionali c intercategoriali." In II Sistema retributivo verso gli anni "90. Napoli: Jovene, pp.177-189.

Blau F. and L. Kahn 1993. "The Gender Eamings Gap: Some International Evidence." In R. Frectian and L. Kalz (eds.), Differences and Changes in Wage Siniciures, Clicago: University of Chicago Press.

Bordogna L. 1988, "Differenziali retributivi, sindacalizzazione c rincorse salariali." In /l Sistema retrilutivi verso gli anni 90. Napoli: Jovene, pp.215-230.

Cannari L.. G. Pellegrini, and P. Sestito 1989, "Readiti da lavoro dipendente: un'analisi in tcrmini di eapitale unlituo." Teni di discussione del Servizjo Studi, Bauca d'ltalin, n.124, pp.5-75.

Carinci F. 1987. "LEvoluzione Storica." In "Inquadramento dei Lavoratori," Quaderni di Diritto del latoro e delle Relazioni indiestriali, n.1. Torino: Utet, pp.12-39.

Carniti Conmision 1988, I Salari in Malia negli anni Ontunst. Venezia: Marsilio, pp.5-233.

C.N.E.L. 1981, Inflazione e Scala Mobile., Quademi di docunsentazione C.N.E.L., Pp.3-147.

Dallago B. 1988, L'Economia Irregolare, Milano: Franco Angeli.

1990, The Irregular Econonty, Hants: Dartnoud, Publislung Conupany.

Deaglio M. 1984, Economia Sommersa e Analisi Economica. Torino: Giappichclli.

D'Apice C. 1975, La Scala Mobile dei Salari. Roma: Editrice Sindacale Italiana, pp.2-37.

Di Bella G. and V. Parisi 1992, "Il prelicvo fiscale c la redistribuzione del reddito nel lavoro dipendente." In R. Brunctla (ed.), Retribuzione, costo del lavoro, livelli della contrattazione: Analisi quantilative. Ricerca CNEL, Etas libri.

Edin P. and B, Holmlund 1993. The Swedish Wage Structure: The Rise and Fall of Solidarity Wage Policy." In R. Frocman and L. Kalz (cds.), Differences and Changes in Wage Stnicutres, Chicago: University of Chicago Press. 
Faustini G. 1987, "A New Method of Indexing Wages in Italy." Labour, 1, pp.71-91.

Frey L. 1988, "Differenziali retributivi c 'job evaluation'." In /l Sistema retributivo verso gli unni '20. Napoli: Jovene cditore, pp.198-200.

Giugni G. 1984, "Recent Trends in Collective Bargaining in Italy," Intemational Labour Review", Sept. - Oct.

Hibbs D. and H. Locking 1991. "Wage Compression, Wage Drift, and Wage Inflation in Swcden." FEF minico.

Iclino P. 1992, II Lavoro subordinato: definizione e inquadramento, Artt. 2094-2095. Milano: Giuffrc' Editorc, pp.3-405.

Katz L., G. Loveman and D. Blanchllower 1993, "A Comparison of Changes in the Struclure of Wagcs in Four OECD Countries." In R. Freeman and L. Katz (eds.), Differences and Changes in Wage Structures, Chicago: University of Chicago Press.

Katz L. and K. Murphy 1992. "Changes in Relative Wages, 1963-1987: Supply and Denand Faciors," Quarterly Joumal of Economics, Vol. CVII, pp. 35-78.

Locke R. 1992, "The Demise of the National Union in ltaly: Lessons for Comparative Industrial Relations Theory," Indusirial and Labor Relations Review, Vol. 45, No. 2, pp. 229-249.

Lucifora C. and G. Presutto 1990. "Retribuzioni lorde e nette." In Occupazione e Retribuzioni. Milano: Assolounbarda, pp.121-155.

Mare R. and C. Winship, Current Population Surveys: Uniform March Files, 1964-19S8 Computer File. Madison, WI: University of Wisconsin, Center for Demography and Ecology producer. 1989. Ann Arbor, MI: Inter-university Consortium for Political and Social Research distributor, 1990.

Mariani I.F. 1991, "Profili storici della discjplina della Scala Mobile." In Scala Mobile: storia e prospettive. Roma: Notiziario di giurisprudenza del lavoro, pp-59-87.

Mattei F. 1981, "Coninkent." In Inflazione e Scala Mobile, Quademi di documentazione C.N.E.L., pp.125-147.

Ministero del Lavoro c della Previdenza Socinle 1988-1991, Labour and Eniployment Policies in Italy. Anmual Reports. Romn, Istituto Poligralico e Zecea dello Stato.

Nardecchia L. and S. Patriarea 1992, "ll prelievo fiscalc sulle retribuzione negli anni 80: lincidenza formale." in R. Bruncua (cd.), Resribuzione, costo del lavoro, livelli della contrattuzione: Analisi guantitative. Ricerca CNEL, Etas libri.

Neufeld M. 1960, /laly: School for Awakening Nations. Ihaca, N.Y.: ILR Press.

OECD 1992, Employment Ontlook, Paris, July. 
OECD 1978-1990, Quarterly Labor Force Statistics, Paris.

Quarchioni R. 1979, Storia della Scala Mobile e Valori dell'Indennita di Contingenza nel setrore industriale dal 1954 al 1979. Milano: Pirola Editorc. pp.7-209.

Rey G. M. 1985, "Influenza del Somnierso sulla Formazione del Prodotto literno Lordo." In /l Sommerso. Realt ed Influenza dell'Econonia Irregolare, Procecotings of uke Conference organized by the Centro "Giovanni Marcora", Torino, February 15-16 1985. Novara: Europnra.

Ricciardeli M. 1992, "Il prelicvo fiscale sulle retribuzione negli anni 80: l'incidenza effettiva." In R. Brunctla (ed.), Retribuzione, costo del lavoro, livelli della contratlazionte: Analisi quantitative. Riccrca CNEL, Etas libri.

Sestito P. 1990. "Empirical Eamings Functions in a Decade of Turbulence: the Italian Experience." Banca d'Ttalia: Servizio Studi. Mimeo, pp. 2-20. 